\title{
The Road to the Citadel as a Chain of Opportunity: Mamluks' Careers between Contingency and Institutionalization
}

\author{
Kristof D'hulster
}

In the weeks following the demise of the Mamluk sultan al-Ashraf Barsbāy in Dhū l-Hijja 841/June 1438, although he was immediately-indeed automatically_ succeeded by his son, al-Azzìz Yūsuf, there ensued a struggle for the sultanate. ${ }^{1}$ The protagonists here were the amirs Jaqmaq and Qurqumās. Of these two, it was the former who emerged victorious as the next sultan, alZāhir Jaqmaq. His opponent, Qurqumās, paid dearly for his failed attempt, and was executed in December of the same year. It therefore appears that in spite of being succeeded by his son, Barsbāy's death sparked off a struggle for the sultanate, and opened up the road to the citadel for a number of Mamluk contestants, all equally eager and seemingly equally eligible to force their way into the citadel and to become the next sultan.

While the short-lived sultanate of the fourteen-year-old al-Azìz Yūsuf is interesting enough in its own right, my focus here will not be the issue of underage rule and its common conceptualization as a mere stopgap in a faltering political system. In fact, neither this nor any other similar struggle in fifteenthcentury Mamluk history will be dealt with in much detail here. The reason why I refer to this episode nonetheless is that it provides the historical backdrop for the question raised in this chapter. My central question here is informed first and foremost by bringing together two seemingly disparate quotations: one in relation to the episode above, taken from Ibn Taghrībirdì's chronicle, al-Nujūm al-Zāhira fı Mulūk Miṣr wa-l-Qāhira ("Stars that Shine among the Kings of Egypt and Cairo"); the other is taken from one of the famous speeches or orationes of the Roman author and politician Marcus Tullius Cicero, the De Lege Agraria contra Rullum ("On the Agrarian Law Proposed by Rullus"). Agreed, it

1 This chapter was originally written in the context of the project "The Mamlukisation of the Mamluk Sultanate: Political Traditions and State Formation in Fifteenth-Century Egypt and Syria' (UGent, 2009-14); this project has received funding from the European Research Council (ERC) under the European Union's Seventh Framework 'Ideas' program (Starting Grant agreement No 240865). 
is a long way from Ibn Taghrïbirdì's fifteenth-century Cairo to Cicero's firstcentury вСЕ Rome. Yet, as will be argued, juxtaposing these two quotations nonetheless makes sense, as bringing in the second allows me to problematize the first; and combined, they provide the perfect backdrop for the research question which I will introduce below. Sultanate ex virtute or ex officio?

As already stated, Qurqumās was defeated by Jaqmaq, and his undoing was, in the words of Ibn Taghrïbirdī, that harraka Qurqumās li l-ruküb fi ghayr waqtihi: the fact that Qurqumās "had made his move untimely" or "at the wrong time". This quotation seems clear enough: the "time" Ibn Taghrïbirdī was referring to was - obviously - a particular moment in the course of the struggle. Put differently, Qurqumās' problem was not that he was not entitled to make a move for the sultanate but that tactically, he did so at an ill-chosen moment during the struggle. In short, the author was saying that Qurqumās was eligible for the sultanate, just like Jaqmaq, but unlike Jaqmaq was a poor strategist.

However, in light of the second quotation, taken from Cicero's De Lege Agraria, another possible interpretation emerges. In his oration, Cicero referred to the Roman cursus honorum, a strict sequence of four offices, each attainable only at a certain age, and culminating in the office of consul. As such, this Roman cursus was an institutionalized course of honors, fixed first by precedence and later codified into a Roman lex. In this particular oratione, Cicero boasted that he had held each of the four successive offices suo anno, "at the youngest possible age", thus having run through this cursus at maximum speed:

(...) I am the only one of all the new men whom we can remember who have stood for the consulship the first moment that by law I could,- who have been elected consul the first time that I have stood (...) (and) this honour which you have conferred on me, ha(s) been sought by me at the proper time. $^{3}$

2 Ibn Taghrïbirdī, Nujūm, 7: 30.

3 The full passage runs as follows: "You will find that those new men who have at any time been made consuls without a repulse, have been elected after long toil, and on some critical emergency, having stood for it many years after they had been praetors, and a good deal later than they might have done according to the laws regulating the age of candidates for the office; but that those who stood for it in their regular year (quit autem anno suo petierint) were not elected without a repulse; that I am the only one of all the new men whom we can remember 
By bringing into this discussion Cicero's suo anno and the Roman cursus honorum ${ }^{4}$ I suggest that we reconsider Ibn Taghribirdī's comment over the 1438 incident, by problematizing the very referential meaning of the author's "time": was he perhaps referring not to a particular ill-chosen moment in the course of the struggle, but to a particular moment in Qurqumās' personal career? That is, was the problem not that Qurqumās was a poor strategist, but rather that he was not entitled to run for sultan in the first place, as he, unlike Jaqmaq, had not yet reached the proper career position to do so? As Cicero would have it, perhaps Qurqumās' run for sultan was not suo anno, but 'institutionally premature"? 5

who have stood for the consulship the first moment that by law I could,- - who have been elected consul the first time that I have stood (me esse unum ex omnibus novis hominibus de quibus meminisse possimus, qui consulatum petierim cum primum licitum sit, consul factus sim cum primum petierim); so that this honour which you have conferred on me, having been sought by me at the proper time (ad mei temporis diem petitus), appears not to have been filched by me on the occasion of some unpopular candidate offering himself,-—not to have been gained by long perseverance in asking for it, but to have been fairly earned by my worth and dignity. This, also, is a most honourable thing for me, $\mathrm{O}$ Romans, which I have mentioned a few minutes ago, - that I am the first new man for many years on whom you have conferred this honour,- that you have conferred in on my first application, in my proper year (quod anno теo)" (Latin text : Cicero, M. Tulli Ciceronis Orationes, speech 2, chapter 2; English translation: Cicero, The Orations of Marcus Tullius Cicero). See also Wex, "On the Leges Annales of the Romans", and, more generally, Beck, Karriere und Hierarchie.

4 Quoting Cicero is not to be read as an implicit claim that the Roman Empire and the Mamluk Sultanate, with their Praetorians and mamlüks respectively, converge in this way or any other (see Irwin, The Middle East in the Middle Ages, 7). There are striking similarities (such as the Roman tres militae and the Mamluk three-tier military ranking of amirs of 10, $5^{0}$ and 100), yet such superficialities hardly warrant sweeping claims.

Nonetheless, more deliberate comparisons might prove rewarding. Alongside the amicitiakhushdāshiyya parallel hinted at by Irwin (p. 89), one could compare, e.g., their commemorative practices, by juxtaposing Roman epitaphs and entries on mamlüks in the biographical dictionaries, and exploring the way in which the cursus honorum are recorded therein. (See here e.g., Meyer, "Explaining the Epigraphic Habit in the Roman Empire"). Turning to the vexed issue of the Mamluk mode of sultanic succession (dynasty vs. tanistry, heredity vs. merit), why not consider the Roman case (an imperial dynasty vs. a "Republican façade", a "de facto monarch" vs. a "de jure princeps")? Didn't Barqūq and Augustus, both "de jure" no more than primi inter pares, strive to found a dynasty around their respective households (the bayt Barqūq and the domus augusta)? Particularly enlightening here is Hekster, Emperors and Ancestors.

5 Throughout the chapter, "institution" is not to be understood in its broader sense, as a structure of social order, but rather as convenient shorthand for "formal political institution" (cf. Pierson, Politics in time, 104). It relates to political offices that come with a "form", be that a diploma, a robe of investiture, a fixed seating or standing positions, etc., "formal" thus being understood, quite literally, as "having an outward form", without implying (yet not precluding) "actual substance". It is not without reason that I prefer to use "formal" 
When confronted with the question as to how understand "time" in the given context, I argue that Mamlukologists will most likely go with Qurqumās, the "poor strategist", and not with Qurqumās, the "institutionally premature" Mamluk. In their eyes, surely Ibn Taghrībirdī must have been referring to an ill-chosen moment in the course of the fight. Surely Qurqumās must have been "allowed" to play the game and run for sultan, just as Jaqmaq. Surely there was no Mamluk qānūn or $y \bar{a} s a$, either written or unwritten, which, as an equivalent to the Roman lex Villia Annalis, would have stipulated temporal and institutional constraints on the sultanate. Obviously, this is not to say that Mamlukologists have thus far thought of the sultanate as something fully "unconstrained", that is, open to all. Apart from the obvious numerical constraint (that is, that there can only be one sultan), scholars have rightfully observed that, if one was not the son of a sultan, one had to be a mamlük in order to become one. ${ }^{6}$ So, at the very least, there must have been a "mamlük constraint". ${ }^{7}$ Writing in the 1930s, Gaston Wiet suggested that there was no other constraint on the sultanate than this broad "mamlük constraint"; and that all mamlüks would be equally eligible to the sultanate: "C'est un monde bien étrange que ce milieu des Mamlouks, qui, presque tous, croyaient 'porter dans leur giberne' le sceptre du sultanat". 8 Finding the pool of eligible Mamluks to be slightly less broad, later Mamlukologists have amended this statement by adding more constraints, albeit still broad and/or ill-defined ones. One commentator, Levanoni, added an "amiral constraint", stating that all amirs-and thus, by implication, only amirs-were eligible for the sultanate. ${ }^{9}$ Another, Holt, narrowed down the pool of eligible mamlūks to "the Royal Mamlūks, and indeed (to) a smaller

(and in the following, as its opposite, "informal") to other dichotomies found in the literature: this particular dichotomy, far more than the others, leaves open the question as to whether the "form" comes with actual substance or not (i.e. whether it comes with power in its own right or not). As this is precisely one of the questions dealt with here, this is a crucial subtlety. Unlike, e.g., "titular power", "formal" allows me to label those aspects that I want to investigate in terms of agency, without already attributing some agency to them.

6 Sultan-caliph al-Musta'īn bi-llāh (r. 815/1412) is exceptional, in that he was neither a mamlük nor the son of a sultan.

7 This constraint itself is hard to unpack; yet, prima facie, it must have subsumed a gender constraint (being male, not female), a military constraint (having a mamlük military training), a social constraint (being part of a mamlük network), and, perhaps, an ethnic/linguistic constraint. For a discussion of the spatial dimension to Mamluk identity, see Garcin, "The Regime of the Circassian Mamlūks", 310; and especially Loiseau, "Lémir en sa maison".

8 H. Munier \& G. Wiet, Précis de l'histoire d'Égypte par divers historiens et archéologues: L'Égypte byzantine et musulmane (Le Caire : Institut français d'archéologie orientale du Caire, 1932), II: 238 (quoted in Holt, "The position and power of the Mamlūk Sultan", 240).

9 Levanoni, "The Mamluk Conception of the Sultanate", 376. 
inner circle of these". ${ }^{10}$ Thus, in the eyes of Wiet, Levanoni and Holt, and arguably, in the eyes of most Mamlukologists, Jaqmaq and Qurqumās, both "Royal Mamlūk" and ostensibly members of their "inner circle", were equally eligible for the sultanate. Thus, for many Mamlukologists, the sultanate was not open to all, but it was at least open to both Qurqumās and Jaqmaq. Qurqumās being the worse strategist of the two, his failure was one ex virtute; Jaqmaq being the best strategist, his success was also ex virtute. Indeed, Jaqmaq is considered the "Heerkönig", 11 emerging victorious "from the coterie of contenders for the imperials office", 12 and from the "factional strife (that) remained the key to power".13

Yet, I wonder, is that all there is to the matter? Is the sultanate truly at the mercy of an "institutionalized competition"14 among all those Mamluks who belong to the "inner circle of Royal mamlüks"? Unlike with the Roman cursus honorum, are there no more stringent and explicit constraints on the sultanate, be they temporal, institutional or otherwise? ${ }^{15}$ Was the mamlūk's age, for example, irrelevant when running for this or that office? ${ }^{16}$ Did not his previous

10 Holt, "The position and power of the Mamlūk Sultan", 241.

11 Sievert, "Family, friend or foe?", 112, note 159.

12 Petry, Protectors or Praetorians, 20. This somewhat disparaging quotation should not be taken as a slight on an otherwise excellent monograph.

13 Levanoni, "The Mamluk conception of the sultanate", 374. Chamberlain captures this as "political dexterity" (Knowledge and Social Practice in Medieval Damascus, 94: "As manșabs [i.e., non-political offices] were not inherited or attained through examination, and there was no concept of a 'right' to them, acquiring and holding on to a manșab was usually a reward for political dexterity") while for Petry "adroitness" is the key term (Protectors or Praetorians, 79: "an effective, if brutal, system of mobility by merit that rewarded the adroit").

14 Darling, "Political Change and Political Discourse", 512. Obviously, this competition can be considered "institutionalized" only when the latter is understood broadly. Hence, this quotation by no means contradicts the gist of the chapter.

15 Another aspect hardly touched upon in discussions on mamlük "career development" is "honor" and its counterpart, "disgrace". In fact, 'izza, nāmūs and related concepts remain grossly understudied, even though they deserve as much attention as (again!) their Roman counterpart of dignitas.

16 As Garcin aptly put it, by the fifteenth century, "the initial rhythm of Mamlūk political life (had) much slowed down", meaning that mamlüks "came to power later and later in life", and, by consequence, those who made it to sultan all "belong(ed) to senior age groups". ("The Regime of the Circassian Mamlūks", pp. 293). However, we may suspect this to be a social constraint in temporal "disguise" (i.e., a strong social network), rather than a veritable temporal constraint (i.e., a stringent age requirement for the sultanate). For the (unrelated) issue of the age of sultan-sons, see, among others, Hirschler, "He is a child and this land is a borderland of Islam"; Stewart, "Between Baybars and Qalāwūn"; Van Steenbergen, "Is anyone my guardian...?". 
tenures, their specific sequence and their respective terms matter the least when running for sultan? In all fairness, it must be acknowledged that, perhaps, some Mamlukologists might beg to differ, arguing that Qurqumās' failure makes sense, since the case of Qurqumās versus Jaqmaq is not just one of "institutionalized competition" among institutionally undifferentiated peers. These may have picked up a clue already left by David Ayalon in the 1950s. In his short entry on the atābak al-asākir in the first edition of the Encyclopaedia of Islam, Ayalon stated that the atābak

became the most important amir in the Sultanate, his functions (being) much broader than the name of the office indicates. For all intents and purposes he had become the sultan's viceroy [...] It was common, especially in the Circassian period, for him to succeed the sultan on the throne. ${ }^{17}$

Working from this observation and from other clues scattered throughout the literature-using information which is more often implicit than explicit and never detailed in any way - these Mamlukologists might have come to think of the office of atābak as the key to the sultanate, and might thus add the atäbakiyya as another, more stringent constraint on the sultanate. For them, it might make sense that Jaqmaq made it to sultan, not Qurqumās. After all, it was Jaqmaq who held the atäbakiyya at the sultan's death, not Qurqumās! Yet while these Mamlukologists might think of the atäbakiyya as the key to the sultanate, I believe that even they will be reluctant to recognize this institutional constraint on the sultanate as a rule proper. Qurqumās' failure may make sense, given Jaqmaq's atābakiyya, but, surely, neither the former's failure nor the latter's success can be explained ex officio! Levanoni and Sievert offer two good cases in point here. In her entry on the atäbak in the Encylopaedia's third edition, thus updating Ayalon's entry from the first edition, Levanoni does not think of the atäbakiyya as a rule proper. Instead, she reduces it to a mere advantage: "In such periods of political transition (e.g. the death of the sultan), the atābak held an advantage in seizing power over other magnates holding positions in the sultan's court".18 For Levanoni, Jaqmaq remains first and foremost the "Heerkönig", emerging victorious from the "institutionalized competition" among the "inner circle of Royal mamlüks". The same observation holds true for Sievert. On the one hand, Sievert is careful to point out the

\footnotetext{
17 Ayalon, "Atābak al-'asākir"; idem, "Studies on the Structure of the Mamluk Army III", 58-59.

18 Levanoni, “Atābak (Atabeg)".
} 
role of the atābak, "one of the old regime's leading amirs", who would often become "the real successor". 19 Yet, in the end, even for Sievert, when a sultan died,

several rivalising factions started to struggle for succession. As each factional leader, usually an amir of the highest rank (...) could only rely on his extended household as well as a number of clients (...) rivalising factions started to form and fight each other until the most powerful and shrewd amir could decide the conflict in his favour (and) became sultan. ${ }^{20}$

So it seems that, in spite of Ayalon's cogent observations on the rule of the fifteenth-century atābakiyya as an institutional constraint to the sultanate in the 1950s and 196os, to date these observations seems to have been mimicked at best, downsized or at worst, even ignored. How to explain the apparent reluctance to think of the atābakiyya as a rule proper? Why can this only be-at most-a "rule"?21

I deal with this question in three successive sections: from 'The atäbakiyya as a "rule", through 'A genealogy of reluctance', towards 'The atābakiyya as a rule in the making?' As Ayalon's statement has not been explicated to date, the first section of this chapter outlines the empirical basis that informed his statement, by mapping the "road to the citadel" from an institutional point of view. ${ }^{22}$ Was it indeed "common for (the atäbak) to succeed the sultan on the throne"? Answering this in the positive, that there is in fact a "rule", I then address the question of why this "rule" appears to not have been fully explicated nor considered in its broader ramifications, instead being mimicked at best, downsized at worst. Taking a reflexive turn in this second section, I offer a "Genealogy of reluctance". That is to say, I explore the reasons why we-myself

19 Sievert, "Family, friend or foe?", 111.

$20 \quad$ Ibid., 109.

21 In the following, I capture the apparent reluctance to rethink the atäbakiyya as a rule proper by referring to it as a "rule" with inverted commas. Thus, rather than identifying a verbatim quotation from an author, these inverted commas are used here as convenient shorthand for capturing this reluctance. For such use of inverted commas, known also as scare quotes, see Finnegan, Why Do We Quote, 50: quotation marks are "also used for expression an attitude to words, allowing participants to both use words and dissociate themselves from them. They could indicate that the speaker regarded something as (...) 'a word that isn't the exact word I want', or 'to indicate that they are using a word or phrase that they would not normally use"'.

22 Yalçın uses a similar metaphor when discussing the nä̉ib al-salțana in the early Mamluk period ("A path to throne among the Mamluks" [sic]). 
included ${ }^{23}$ - tend to settle with a "rule" (that is, with inverted commas) at most. In the third section, I move "Towards the atäbakiyya as a rule in the making". I reflect on the consequences of dropping the inverted commas and explore how this reframing comes to bear on broader processes of institutionalization and state (trans)formation in the Mamluk sultanate and beyond. Following some final thoughts are two supplements: first, an excursus on three further aspects relating to the atābakiyya; second, a table of atābak al-'asākirs for the period in question.

While a detailed study of Mamluk career trajectories and their possible constraints is a definite desideratum for future scholarship, it is beyond the scope of a short chapter such as this. For now, I focus on the upper end of the "road to the citadel" during the fifteenth century, ${ }^{24}$ and on the role of institutional constraints, to the exclusion of temporal ones.

\section{The Atäbakiyya as a "Rule": An Institutional Reading of Fifteenth- century Mamluk History}

In this section, I explicate the pivotal role of the atäbakiyya as observed by Ayalon and others, by laying out the empirical basis behind this observation. Whereas the inverted commas of this "rule" are dealt with in the following section, here it is the rule itself that is unpacked. Rather than working backwards from the "rule", I think it wise to work the other way around, starting from the data. I do this by looking at the pre-sultanic careers of Mamluk sultans through a strictly institutional lens, that is, by rewriting these social trajectories as sequences of offices held prior to accession. Do these sequences display a common institutional factor-either in terms of offices held or in terms of their respective chronological order - that moves beyond the sweeping category of being a "Royal Mamluk amir", and thus add a more stringent constraint on the sultanate? To return to our Roman parallel, was there a Mamluk cursus honorum, an institutionally fixed road to the citadel, with clearly identifiable steps

23 In this section and elsewhere, I switch from the first person singular to the first person plural. This "we" is neither indicative of poor editorship, nor is it to be mistaken for a pluralis majestatis. Instead, it functions as a pluralis auctoris. Far from being a shallow attempt to eschew the more responsible "I" presentation, I use it most consciously for expressing particular understandings that are shared—or so I argue-by myself and other Mamlukologists.

24 As for its lower end, Garcin offers the generic observation that "promotions of grand amìrs generally followed ascending order of rank", but he does not explicate this any further ("The Regime of the Circassian Mamlūks", p. 305). 
in a sequential order, each of which coming with their own possibilities for further promotion, and crowned as it were by the highest office of all, the sultanate? If there is no such thing, then clearly, Ibn Taghribirdì must have meant that Qurqumās was a poor strategist. If there is such a thing, then he might have meant that Qurqumās' move was institutionally premature and that he had not ascended high enough up the cursus honorum to run for sultan.

Obviously, by reducing the sultans' social trajectories to office sequences, I am making full abstraction of all other data available on these sultans, abundant data that ranged wide in scope (financial means, military skills, piety, charisma, pedigree, ethnicity, networks, physical characteristics, ...), and that-I know all too well-must have mattered. Of all these types of "capital", to use Bourdieu's terminology, it is arguably "social capital" that has received most attention in recent years. This is deservedly so, for what mattered a great dealperhaps more than anything else-was the sum total of people whom one could engage/by whom one could be engaged, ${ }^{25}$ whether by invoking sanguine, marital, patrimonial, mamlük, or some other type of ties. However, it is easy to feel blinded rather than elucidated when confronted with these abundant data on networks and other variables. An obvious way out of such a conundrum is to make abstraction, and this is the approach I take here. Using Algazi's "hands off rule", ${ }^{26}$ from all data available I will retain only the sequence of offices. It goes without saying that limiting myself to "institutional data" at the expense of other "extra-institutional data", comes at a cost. Indeed, rather than a novel or valid paradigmatic "turn", this could even be seen as an unwarranted and

25 While the concepts of "friend" and "patron" might appear very different to the modern mind (the first one implying "equality" and the second one implying "inequality"), the Mamluks could express both these concepts with one and the same word, șăhib. This observation immediately reminds us of Mauss' seminal work on do ut des, "Essai sur le don" (for which, see, e.g., Algazi, Groebner \& Jussen, Negotiating the Gift; Rustow, "Patronage in the Context of Solidarity and Reciprocity"; as well as the works of S. Gordon and I. Krausman Ben-Amos). On the Mamluk practice of gift giving, see mainly the publications of D. Behrens-Abouseif, E.I. Muhanna, and M. Springberg-Hinsen. Eychenne (in "Le bayt à l'époque mamlouke", 277-283) offers an inspiring lexico-semantic study of the Mamluk vocabulary of "friendship" and "patronage" (compare to Hellegouarch, Le vocabulaire latin des relations). A general discussion is given in Nicols, Civic Patronage in the Roman Empire, 2.

26 I borrow this phrase from Algazi ("Comparing Medieval Institutions", 3), who, in another, yet reminiscent context, argues that "(s)ome of the advantages of the focus on institutions would be familiar to any practitioner of the craft of history. Most importantly, it imposes a few useful limitations, a few simple 'hands off rules' for comparative historical research: No invocations of mysterious 'mentalities' to explain (....) No summary invocations of 'culture' as a summary explanation of differences between historical, differentiated societies-not even of culture's older sister, 'religion'”. 
unwanted "re-turn" to the past! This pitfall, however, is duly recognized, and I return to it later on. ${ }^{27}$

Let me therefore consider, for example, the offices held by sultan al-Zāhir Khushqadam (r. 865-872/1461-1467) prior to his accession. ${ }^{28}$ Some time after being imported into the Egyptian domains in 815 or 816, aged 8 or 9, Khushqadam was purchased by sultan al-Mu'ayyad Shaykh, thus becoming a mamlūk kuttābì. Being then manumitted by Shaykh, he made it to mamlūk sulțānī. In 824, under the short reign of Shaykh's son, al-Muzaffar Ahmad, Khushqadam rose to the rank of khāsș̣aki. During the sultanate of al-Zāhir Jaqmaq, Khushqadam steadily kept climbing the ranks, moving from sāqū in 842, through $r a$ 's nawba and amìr of 10 in 846, and amir of 100 in Damascus in 850, up to häjib hujjāb and amir of 100 back in Egypt in 854. In 857, at the onset of his sultanate, al-Ashraf Īnāl appointed him as amir silāh. Immediately following the sultan's death in 865 , the latter's son-successor, Ahmad b. Innāl finally appointed the 58 year-old Khushqadam as atäbak al-asākir. At last, some four months later, atābak al-'asākir Khushqadam was able to oust the sultan-son al-Mu'ayyad Ahmad, and to seize the sultanate himself.

It is thus clear that Khushqadam's last pre-sultanic office was that of atäbak al-'as äkir. As for the office itself, commonly translated as "commander-in-chief of the armies", it is not necessary here to explain either its origins or its duties and prerogatives. ${ }^{29}$ Suffice to say that on the whole, the atābak had no duties "except those of leading the armies in action" (and in this capacity he could be replaced by the muqaddam al-asākir or "(acting) commander of the armies"), and, generally, "sitting on the sultan's advisory council". ${ }^{30}$ What is interesting about the atäbakiyya in the present context is the fact that this was the last pre-sultanic office held by a significant number of sultans in the period in question here (815/1412-901/1496, from al-Mu'ayyad Shaykh, r. 815-824/14121421, up to al-Ashraf Qāytbāy, r. 872-901/1468-1496). Out of a total of fourteen

27 See Pierson's observations on the role of prior expectations in research and on the need to "think through these" explicitly and carefully (Politics in Time, 7).

28 Succinctly presented by Ibn Taghrïbirdì (Nujūm, 7: 687-689).

29 See 'Abd al-Jawād, "Atābak al-'asākir fī l-Qāhira" (non vidi); Ayalon, "Studies on the Structure of the Mamluk Army-III", 58-59 and 81-85; idem, "Atābak al-'asākir"; Holt, "The structure of government in the Mamluk Sultanate", 53-55; Levanoni, "Atābak (Atabeg)"; and Popper, Egypt and Syria under the Circassian Sultans, 90-91. Cahen ("Atabak") provides a general aperçu, while Eddé ("Quelques institutions militaires ayyoubides", 163-174) deals with its Ayyubid precursor. References to the administrative manuals of al-Qalqashandī, al-'Umarī and al-Ẓāhirī can be found in these titles.

Popper, Egypt and Syria under the Circassian Sultans, 90-91. 
sultans, ${ }^{31}$ no less than eight had moved directly from the atābakiyya to the sultanate:Shaykh, Jaqmaq, Innāl, Aḥmad b. Īnal, Khushqadam, Yilbāy, Timurbughā, and Qāytbāy. ${ }^{32}$ As such, these eight sultans followed a precedent created by al-Zāhir Barqūq (r. 784-791/1382-1389 and 792-801/1390-1399), who, from his position as atābak al-'asākir, deposed the last puppet-sultan of the Qalāwūnid household in 784/1382, and subsequently proclaimed himself sultan. ${ }^{33}$ The empirical data thus confirms the "rule" of the atäbakiyya: as David Ayalon had already observed for the first time in the 1950s, clearly this office was indeed the key to the Mamluk sultanate. ${ }^{34}$ As already stated, the inverted commas of this "rule" will be examined in the next section. Before doing so, however, it is worthwhile to first elaborate on this "rule" by taking a closer look at the list of the atäbak 'asākirs for the period under scrutiny, tabulated at the end of this chapter. ${ }^{35}$

First, it appears that, as a "rule", sultans are succeeded by their last atābak. For example, sultan al-Mustaīn is succeeded by his atābak Shaykh, Yūsuf b. Barsbāy by Jaqmaq, and Timurbughā by Qāytbāy. So the atābakiyya appears to have been the institutional key par excellence to unlock the gates of the citadel. The sources do in fact confirm this intimate link between the atäbakiyya

31 One should keep in mind that, of the total of 14 sultans, 5 were sultans-sons, who, as such, operated outside of the Mamluk cursus honorum. See the table for more details.

Of the many references, the most apt are Ibn Taghrībirdī, Nujūm, 6: 323, 7:423, 764, 822, 825, 849, 865; Ibn Taghrïbirdī, Manhal, 9: 58. The fact that Ibn Taghrïbirdì's father himself was the atābak just before the period in question $(810-813 / 1407-1410)$ adds an interesting psychological dimension.

33 This is not to say that the office of atäbak was not important before Barqūq. On the contrary, already before this time atābaks were often effectively the strongest of the Sultanate (think for example of Qalāwūn, atābak of sultan Salāmish b. Baybars in the 127os). Yet, unlike atābak Barqūq, Barqūq's predecessors continued to function under the legitimizing institutional umbrella of a Qalāwūnid dynasty, rather than claiming the institutional highest authority for themselves.

34 Brinner ("The struggle for power in the Mamlûk state") correctly identified the move of Barqūq from atābak to sultan as a pivotal moment in history of the former office. Thus ending "the fiction that had grown up around the title of sultan", Brinner continues, Barqūq had also "destroyed the significance of the office of the atābak so that thereafter it was essential for an ambitious amir to seize the sultanate for himself". "The struggle for power in the Mamlūk state", 233-234). Somewhat carelessly worded, this statement may hence be easily misunderstood. Undoubtedly, what Brinner wanted to convey was not that the atābakiyya itself had become irrelevant, but rather that the atābakiyya ceased to be the highest office a mamlük could aspire to obtain.

35 The number of references in the table has been kept to a minimum, and the dates are as accurate as possible. As for sultans' sons, only those who made it to sultan are included, and their ages are given only when relevant. As for vacancies, only the longer ones are indicated explicitly, while the shorter ones can be inferred from the gaps in dates. 
and the sultanate. Immediately following sultan Yilbāy's appointment of Timurbughā as atābak, "everybody was convinced that the power would eventually come to Timurbughā, and thus it happened (tahaqqaqa kull ahad anna l-amrya'ūl ilayhi fa-kāna)". ${ }^{36}$

A second observation relates to those cases where a "sultan-son" is involved. If a late sultan has a (grown-up) son, it appears that the same principle holds, only this time operating at an interval. First, the sultan is succeeded by his son. This sultan-son's sultanate, however, is short-lived and before long, he is ousted by the atäbak whom he "inherited" from his father along with the sultanate. Barsbāy, for example, is succeeded first by his son, Yūsuf, who is subsequently succeeded by their joint atābak, Jaqmaq. A second case in point is the sequence of sultan Jaqmaq, his son Uthmān and their joint atābak Innāl. ${ }^{37}$ Thus rewriting the "rule", I might say that sultans are succeeded by their atābak, either immediately, if there is no son, or after a short interval, in case there is one. ${ }^{38}$

Admittedly, even when rewritten, this "rule" has its "exceptions": three to be precise. Yet, as I argue, far from invalidating the "rule", these exceptions corroborate the importance of the atäbakiyya. First, there is the succession of sultan Iñāl by his son, Ahmad, in 865, exceptional in that Ahmad was both the sultan's son and his atābak. ${ }^{39}$ As a matter of fact, al-Ashraf Innāl appointed his son and future sultan, Ahmad, twice as atābak. The first time he did so

36 Ibn Taghrībirdī, Nujūm, 7: 848-849.

37 As appears from the list, Khushqadam, Yilbāy and Timurbughā were not succeeded by a son. This may be due to the fact that they didn't have a son when they passed away (in fact, only Khushqadam appears to have had one, aged 5 at the time of his father's death), or because, by then, the sultans had come to realize that succession by a son (even as a mere stopgap) was no longer an option. Either way, this discussion has little bearing on the present question.

38 As already stated, the sultanate of sultan-sons lies outside the scope of this chapter.

39 This is exceptional in that Ahmad appears to be the only sultan-son who was atābak at the time when the father-sultan died. Already in the 820s, al-Mu'ayyad Shaykh had turned to this same "institutional ploy", appointing his choice son, Ibrāhīm, as atābak. In that case, however, the son did not outlive his father but he passed away, aged 23, some 6 months before Shaykh himself. As atābak, Ibrāhīm was succeeded in office by a mamlūk, Alțunbughā al-Qurmushī (al-Maqrīzī, Sulūk 4: 477, 517; Ibn Taghrībirdī, Nujūm, 6: 476; al'Aynī, Iqd, 1: 231). As sultan, Shaykh was succeeded for some 8 months by another son, al-Muzaffar Aḥmad, aged "1 year, 8 months and 7 days" at the time of accession (alMaqrīīì, Sulūk, 4: 563).

Perhaps, Jaqmaq had appointed his son 'Uthmān, the future sultan, as atābak as well, but the evidence is limited to one single (?) reference to the latter's tenure, in the list of officeholders at the beginning of 857 as recorded in Ibn Taghrībirdī's Hawädith (see Ibn Taghrībirdī, Nujūm, 7: 237, note l: “The atābak al-'asākir is Înāl al-'Alā'ì al-Nāṣiīi (i.e., the future sultan), and (wa) his Excellency al-Fakhrī 'Uthmān, son of sultan (Jaqmaq)"; see also Sievert, Der Herrscherwechsel im Mamlukensultanat, 124). 
immediately following his own accession in 857. Yet, tellingly, this appointment was met with growing unease, and the very next day Ināl felt obliged to rescind his son's appointment. ${ }^{40}$ As Ibn Taghrībirdī explains:

The appointment of the sultan's son to the position of atäbak is an offense against common usage ( $\min$ kharq al-'awäid), for we haven't heard of any of the rulers' sons befalling that (...) The appointment troubled the people (shaqqa dhälika 'alā l-nās). The sultan got word of that and he then set right his faux pas (fa-stadraka fartahu), removing his son and appointing Tanibak instead. ${ }^{41}$

Five years later on, however, in 862, Īnāl was in a strong enough position to reappoint his son as atäbak and to get away with it. In the same chronicler's words,

At a time when the sky had become cloudless for the sultan, he finally achieved what he had aimed at all along (mā kāna fígharadihi), without anyone contending, without word or talk (min ghayr munāzic wa-lā kalām wa-lā $q \bar{a} l a) .{ }^{42}$

This time, Ahmad remained in office until his father died, and then progressed directly from atābak to sultan. What should we make of these two appointments? First, it is clear that Īnāl was acutely aware of the fact that, by then, the dynastic principle of sultanic succession had yielded to a mamlük principle, with "royal blood" no longer a match for a "mamlük identity". Second, and more specifically, he fully recognized the atäbakiyya as the key element to the sultanate's new reality. As he hoped for his non-mamlük son to truly succeed him, thus going against precedent, he thought he could enhance the latter's chances by appointing him atäbak, thereby_perhaps advertently_ "mamlūkizing" him. ${ }^{43}$ In the end, Innāl's "institutional" efforts were nonetheless to no avail, as just four months later Ahmad was deposed by his own atābak, the mamlūk Khushqadam. Ibn Taghrībirdī was somewhat caught by surprise over the quick downfall of al-Mu’ayyad Ahmmad:

$40 \quad$ Ibn Taghrīibirdī, Nujūm, 7: 425-426.

41 Ibn Taghrībirdī, hawādith, 318.

42 Ibid.

43 Jaqmaq appointed his son, 'Uthmān, as atābak because, according to Sievert, "he did not want to burden him with an inherited sultanate" (nicht mit dem "Makel" des ererbten Sultanats belasten) (Der Herrscherswechsel im Mamlukensultanat, 124). 
Al-Mu'ayyad [Ahmad]'s reign came to an end most quickly, as if it had never been (...) in spite of the large numbers of his dependents (hawāshì), his vast possessions and the fact that he was [deemed] exalted in the souls of men ('azamatihifi l-nufüs), as opposed to the other sons of rulers who had become sultan (al-mustalținin min awläd al-mulük) (...) and [in spite of] the fact that he had been made atäbak in the days of his father, for all sons of rulers who were deposed [from the sultanate] were time and again overcome by [the one who occupied] the office of atābak (fainna kull man khuli'a min awlād al-mulūk mà ukhidha illā min jihat alatäbakiyya), but this [man's] father had not had any other atābak than his son. ${ }^{44}$

Hence, rather than an exception, this particular succession episode is a corroborating variation to the "rule" of the atäbakiyya as the key to the sultanate.

A somewhat bigger challenge is posed by the two other cases, the successions of Ahmad b. Shaykh by Ṭațar in 824, and that of Muhammad b. Tațar by Barsbāy in 825. These cases are exceptional in that here the sultan-sons are not succeeded by their respective atäbak, whom they had "inherited" from their father. Instead, their atābak appears to have been "overruled" in his "claim" to the sultanate by another official, the nizäm al-mulk or "regent". Unlike the atäbakiyya, this was an occasional office given by a sultan to an amir in case the sultan-son was still underage. ${ }^{45}$ From an institutional point of view- that is, in light of the "rule" established above-it would make sense for this occasional office to be combined with that of atābak, and indeed, Shaykh, Jānibak al-Ṣufì and Jaqmaq ${ }^{46}$ combined the two offices. The cases of Țațar and Barsbāy, however, are the only examples in which the two offices were split rather than combined. First, under the sultanate of Ahmad b. Shaykh in 824, Jānibak alSūfì held the atäbakiyya, while Țațar was the nizām al-mulk of the sultan-son. The next sultan turned out not to be the sultan-son's atābak, Jānibak, but his nizām al-mulk, Țațar. Second, under the sultanate of Muhammad b. Țațar in 825, Jānibak first combined the atābakiyya and the office of nizām al-mulk. Yet,

\footnotetext{
44 Ibn Taghrībirdī, Hawādith, 396-397.

45 See Popper, Egypt and Syria under the Circassian Sultans, 90.

46 Jaqmaq is only referred to as the mudabbir al-mulk of Yūsuf b. Barsbāy, and not as his nizām al-mulk (Ibn Taghrïbirdī, Manhal, 4: 279), but I assume that the titles have become interchangeable by that time (the fact that Ṭațar, Jānibak and Barsbāy all held the two titles simultaneously might explain the confusion). Thorough research that disentangles the offices of mudabbir al-dawla, lālā, nizām al-mulk, atābak, and the elusive amìr kabìr remains a major desideratum in the field (see, among others, Levanoni, "The Mamluk conception of the sultanate", $383-384)$.
} 
the 'jack-in-the box' Barsbāy appeared on the scene and "finished him off institutionally", by himself becoming the the nizäm al-mulk, and passing on the office of atābak to Ṭarabāy al-Zāhirī. In the end, it was nizām al-mulk Barsbāy who succeeded sultan Muhammad b. Tatạar, and not the former atābak-cumnizām al-mulk Jānibak or the later atābak Țarabāy. So, it appears, if the offices of nizām al-mulk and atäbak are split, it is the nizām al-mulk who "overrules" the atäbak. In relation to these last two episodes, there is a telling confusion in the sources regarding the offices held by the protagonists. In four instances, the nizām al-mulks Țațar and Barsbāy are referred to as atābak. Țațar is referred to like this three times, all by Ibn Taghribirdī ${ }^{47}$ In his Nujüm, for example, the author stated that "the length of (Țatar's) rule, since the death of al-Malik alMu'ayyad Shaykh until he himself died, was eleven months minus 5 days, of which ninety-four days as sultan and the remainder of which as atäbak" (wabāqù dhālika ayyām atābakiyyatihi).$^{48}$ In the Manhal entry of Țarabāy al-Zāhirī, Ibn Taghrïbirdī stated that "al-Malik al-Mu'ayyad Shaykh died in the year 824 and his son al-Malik al-Muẓaffar Aḥmad Abū l-Sacāda became sultan after him [while] Ṭațar became his atābak and nizām al-mulk". ${ }^{49}$ As for Barsbāy, he seems to be referred to as atābak only once. According to Ibn Ḥajar al-'Asqalānī, while on his deathbed al-Ẓāhir Țațar had designated his son Muhamammad as his successor and had appointed al-dawādār al-kabïr Barsbāy as the atäbak al'as ākir. ${ }^{50}$ Apart from these four references, however, there is no further explicit proof of either Țațar or Barsbāy being appointed atäbak, and, consequently, there is little reason to assume that they actually held this office. ${ }^{51}$ Why then are they still referred to as such? If anything, these references are clear proof of the utmost importance of the atäbakiyya, and of its intimate link both with the sultanate and with the office of nizām al-mulk. Both Țațar and Barsbāy had been the nizām al-mulk to the sultan-son, and both eventually made it to become sultan; surely, both of them must therefore have also been atābak, or-if not - might still be referred to as such, as an authorial lapsus! Leaving the office of nizām al-mulk out of the discussion, one might say that, in a way, the

\footnotetext{
47 The third reference, not given here, is Ibn Taghrībirdī, Nujūm, 7: 619-621.

48 Ibn Taghrībirdī, Nujūm, 6: 517.

49 Ibn Taghrībirdī, Manhal, 6: 373-378.

50 Ibn Hajar, Inb $\bar{a}^{\prime}, 7: 425-426$.

51 Not only the small number of references is suspicious, but also the context in which these references are found: mostly capsule biographies and obituaries, and not the day-to-day historiographical recordings. Moreover, for exactly the same timeframe, we find references to other atäbaks that are both more numerous and more explicit (see the table at the end of this chapter). Of course, ultimately, if these suspicions were found to be unfounded, this would only corroborate my basic argument.
} 
connection between atābakiyya and sultanate was so strong that it worked "retro-actively". For, if as a "rule", atäbaks become sultans, then all sultans (sultans-sons excepted) must have been atäbak prior to accession!

Recapitulating this section, I have thus far outlined the empirical basis of Ayalon's generic statement, thus demonstrating the "rule" of the atābakiyya. Indeed, some exceptions notwithstanding, it is the atäbak who becomes the next sultan. This "institutional turn" now needs to be followed by a "reflexive turn": why, in the face of empirical evidence, are we ${ }^{52}$ Mamlukologists reluctant to explicate this "rule" and to consider its broader ramifications? Why do we reiterate it at best, and downsize or omit it at worst? Why are we reluctant to drop the inverted commas of the "rule" and to think of it as a rule proper instead?

\section{A Genealogy of Reluctance: The Circularity of Informality, Networks and Contingency}

In the preceding section, I have demonstrated the potential of a strictly institutional reading as a useful and valid tool. For one, it "suggests" insights which are easily confirmed by extra-institutional data. The fact that İnāl, for example, twice appointed his son as atäbak strongly suggests that he sincerely hoped that his son would succeed him. Indeed, Ināl's fatherly concern can be traced extra-institutionally as well. Moreover, not only does an institutional reading suggest or confirm extra-institutional data, it elucidates this as well, by adding novel and surprisingly clear-cut insights. Apart from suggesting that Īnāl wanted to see his son succeed him, the institutional reading clearly spells out one of the strategies to which the father-sultan turned in order to achieve this: a strategy of institutional mamlükization. To take another example, from an institutional perspective, the split tenure of atäbakiyya and nizām al-mulk, involving Țațar and Barsbāy (as opposed to the combined tenure by Shaykh and Jaqmaq), seems to spell doom, and indeed, the chronicles portray these two sultanic successions as particularly messy and protracted. The case of Jānibak alSunfì is especially revealing in this respect: from an institutional perspective, al-Ṣufi's defeat at the hands of Barsbāy is surely one of the bitterest ones throughout Mamluk history. ${ }^{53}$ At one point, all institutional odds were with Jānibak, and against Barsbāy: it was Jānibak who combined the offices of

$5^{2}$ On the conscious use of this pluralis auctoris here and in the following section, see above.

53 For a biography, see Adriaenssens \& Van Steenbergen, "Mamluk authorities and Anatolian realities". 
atābak and nizām al-mulk to Ṭațar's son, it was he who was to be next sultan! Yet, against all institutional odds, in 1422 he ended up not in the throne hall of the citadel, but first as a refugee in Anatolia, and, finally, in 1438, as a severed head, stuck on a spear and paraded before sultan Barsbāy. What a turn of luck, if there ever was one! Of course, this particular story does not become nonsensical if we leave aside its institutional dimension. Yet, one must agree, the bitterness of Jānibak's defeat and the fact that, in spite of this defeat, he remained Barsbāy's nemesis for many years become all the more clear by adding the institutional dimension as another useful layer of interpretation.

Yet, admittedly, however suggestive or elucidating an institutional reading may be, it has its obvious limits. Think for example of the bitter defeat of Jānibak at the hands of Barsbāy: while an institutional reading allows us to fully appreciate its bitterness, it falls short of explaining how this could happen or why. How could Barsbāy, a "mere" dawādār kabìr, "institutionally finish off" Jānibak, the atābak-cum-nizām al-mulk, and gain the sultanate for himself? A second example is the cases of Yilbāy and Timurbughā: both were atābak to the previous sultan and as expected they did in fact become sultan. Yet, how come they were unable to remain in that position? While I argue that institutions did matter and that, in fact, there were institutional constraints to the sultanate that moved beyond the sweeping category of "Royal Mamluk amirs", it is clear that these facts cannot possibly tell the whole story. Hence, the time has come to bring in the extra-institutional data which so far has been missing from the discussion. By doing so, I will explicate some of the underlying assumptions that, in my view, inform our understanding of fifteenth-century Mamluk socio-political culture. These assumptions, ${ }^{54}$ so I argue, lead to the ascendance of network analysis at the expense of institutional history, to the primacy of historical contingency at the expense of diachronicity, and, ultimately, to the rise of "rules" at the expense of rules proper.

When bringing in the extra-institutional data, the question arises as to whether the institutional and the extra-institutional ${ }^{55}$ relate to one another, and if so, how. While the question of whether these two were related is readily answered in the affirmative by Mamlukologists, we seem to find the question of how this interrelation worked, however, much harder to answer. Especially for the fourteenth century, quite a few authors such as Chamberlain, Clifford and Van Steenbergen have grappled with this question. As I see it, their various

54 Or, as Charles Tilly would put it, "pernicious postulates" (see Tilly, Big Structures, Large Processes, Huge Comparisons, 11$)$.

55 "Extra-institutional" means "all that is not institutional" (itself a shorthand, it will be recalled, for "formal political institutional"). 
understandings share first and foremost a dichotomous conceptualization of the institutional and the extra-institutional, ${ }^{56}$ being referred to as "nominal" and "factual",57 "titular power" and "actual power",58 "legitimate power" and "effective power" (being the "two sides of the same coin"), 59 or "monetized honour" and "political dexterity" ${ }^{60}$ In fact, such dichotomous understanding is not alien to the sources, where it is rendered by the pair of ism, litt. "name", or hiss, litt. "sound", vs. ma'nā, litt. "meaning". For example, someone might be said to be an ustādār "nominally" only, the "factual" ustādār being his ustādh (wawaliya l-ustādāriyya hissan wa-mánāhu ustādhihi).

Ideally then, either side of the coin could serve as a proxy for the other, thus allowing us to use the "nominal side" to talk about the "factual side" and vice versa. In reality, however, we have found that the two sides of the coin don't. The sources sometimes refer to "institutional bubbles". In the most flagrant cases, the "two sides of the coin" have gone out of sync, and individuals are explicitly said to be in power mujarrad al-ism, isman, bi-l-ism or hissan, "in name only, nominally, in a titular manner", while the ma'nā or "factual power" of their office resides with somebody else. ${ }^{61}$ Often, however, such cases are not marked explicitly. Barsbāy vs. Tarābāy is a good case in point here: while none of the protagonists are explicitly said to be in power mujarrad al-ism only, the sources do portray the gradual build-up of an "institutional bubble" and the losing party's growing unease over this fact. ${ }^{62}$ However marked, what we take

$5^{6} \quad$ Hereby not implying that the various authors conceptualize these dichotomies in identical ways.

57 Brinner, "The struggle for power in the Mamlūk state", 232.

$5^{8}$ Stewart, "Between Baybars and Qalāwūn", 47 (with reference to the "potestas/nomen debate").

59 Van Steenbergen, Order out of Chaos, 6-7. Alternatively called "institutions" or "the institutional framework" versus "the individuals that populated them" or "(socio-political) practice".

6o Chamberlain, Knowledge and Social Practice in Medieval Damascus, 92, 94. Himself dealing with non-political offices, Chamberlain recognizes the same mechanics at work for political offices.

61 Using ism, litt. "name", said for example of caliph al-Mu'taḍid bi-llāh (wa-laysa lahu min al-khilāfa illā mujarrad al-ism), of sultans Muhammad b. Țațar, Yūsuf b. Barsbāy, and Yilbāy (șāra huwa sman fì l-salțana wa-l-ma'nā li Khayrbak, the "factual sultan" being Khayrbak), and of kātib al-sirr Muhibb al-Dīn b. al-Ashqar (bi-l-ism lā ghayr) (al-Maqrīzī, Sulūk, 4: 677, 1078; Ibn Taghrībirdī, Nujūm, 7: 839, 838; Ibn Taghrībirdī, Hawādith, 297, 610, 614; Ibn Iyās, Badā’i' al-Zuhūr, 2: 79).

62 See for example Ibn Taghrībirdī, Nujüm, 6: 537-538. Following the death of Țațar and the joint removal of Jānibak by Ṭarābāy and Barsbāy, thus clearing the road to the citadel, these two protagonists had agreed that "the control of the government would be divided between them equally, and that no one would get preference over the other in any matter". 
from these cases is that while they may be interrelated, the interface that links them is not transparent and synchronous, but rather opaque and asynchronous. Ideally, the "nominal side" would "name" "factual" power relations synchronously (that is, fully in sync with factual power relations) and transparently (with neat one-on-one correspondences). In reality, however, it seems to do so a-synchronously (that is, out of sync with factual power relations), and opaquely (that is, without neat one-on-one correspondences).

Conceptualizing the relation of the institutional and the extra-institutional as a dichotomy with a vexed interface, however, comes with serious consequences. First, when we understand institutions as little more than opaque, out of sync or inferior alter egos to extra-institutional power, the question arises as to why one should study "institutions" in the first place. Finding this question difficult to answer, we Mamlukologists have tended to acquiesce to the old saying that it is first and foremost "the man who makes the office honourable, not the office which dignifies the man". Indeed, while we may still see these two sides as alter egos, eventually we settle on the extra-institutional side of things as the "superior" one. ${ }^{63}$ As Chamberlain formulated this programmatically:

Once we look for practices and strategies rather than institutions and rules, at the strategic rather than the taxonomic, we are in a much better position to exploit (politics and social life). ${ }^{64}$

Directing our attention there obviously comes at the expense of all things institutional. A second consequence which ensues from the first is that we have

Before long, however, and in spite of their gentlemen's agreement-indeed, in violation of it-, Țarabāy found himself next in line to be institutionally caught up by his onetime brother-in-arms. A bubble started to build, as the dexterous nizām al-mulk Barsbāy gradually accumulated ever more factual power, draining this from atābak Tarābāy and thus disturbing the carefully negotiated balance of power. By the time that Țarābāy had "come to realize that the situation was the opposite of what he had hoped for", the bubble had grown too large and was readily pricked by Barsbāy.

63 While Van Steenbergen readily acknowledges their interrelatedness and stresses the fact that neither can be properly analysed without the other, his "legitimate power" is explicitly said to come second to the "effective power", the latter being referred to as the former's "superior alter ego" (Order Out of Chaos, 7).

64 Chamberlain, Knowledge and Social Practice in Medieval Damascus, 178. In the words of Clifford ("Ubi sumus?", 53), "Chamberlain has adopted Lapidus' position on "institutional history", arguing that an undifferentiated social formation can be better explained in terms of informal social networks than formal communal institutions". This can be compared to Sievert's call for us to focus on "interpersonal relations between individual actors" ("Family, friend or foe?", 118), and Van Steenbergen's recent observations (“'Mamlukisation' between social theory and social practice", 7-9). 
started to undervalue the individual agents' respective offices (that is, the institutional structure in which these operated), and their institutional trajectories (that is, the previous career tracks that brought them there). Instead, we have come to focus on agents' extra-institutional trajectories, by tracking the ongoing reconfiguration of their economic, social, cultural and symbolic capital, to the extent that the sources allow. Of these various types of capital, we have put social capital center stage, fueled in this by the nature of the sources and by our understanding of Mamluk society as a patrimonial one. The most appropriate analytical tool for mapping social capital was found in network analysis. Hence, to a large extent, "informal network analysis" remains, in the words of Winslow Clifford, "the basic thrust line of Mamluk history". 65

As a third consequence, I argue that this preponderance comes at its own cost. In his sensitive Narrative Social Structure, Recep Şentürk made thedeceptively obvious - observation that social life "is by definition diachronic, since it involves sequential events". Yet, he continues, social scientists "have paid little attention to the diachronic dimension of social structure (...) erroneously conceptualiz(ing) social structure as above and beyond time and constituted only by synchronic relations". ${ }^{66}$ Alternatively, Şentürk calls for social structure to be embedded in diachronic time, although this is no easy task:

The major methodological problems in a study of structure through time (...) stem from the embryonic state of diachronic analytical tools in the social sciences. (....) The query for structures has remained synchronic in focus, thereby creating a gap between diachronic and synchronic analysis of structures. A cross-temporal structure is produced by the enduring patterns of diachronic social relations between actors who are differentiated from each other by virtue of time. Sociological research has concentrated for the most part on the structures produced by the enduring relations between social actors who are differentiated from each other, and thus stratified into different groups, by virtue of economic, social and cultural attributes. However, structural analysis of social relations cannot reach its full potential without developing methods to explore crosstemporal structures. Any analysis that ignores the passage of time and

65 Clifford, "Ubi sumus?", 53. Almost 20 years later, Rapoport observed that "the traditional paradigm of equilibrium achieved through the informal networks of the elite" still looms large ("New Directions in the Social History of the Mamluk Era", 145).

66 Şentürk, Narrative Social Structure, 124. For a penetrating presentation of social scientists' difficulty in infusing "structure" with "temporality", and, vice versa, of historians' difficulty in infusing "temporality" with "structure", see Sewell Jr., Logics of History, a must-read that every historian should grapple with. 
the temporal constraints arising from it produces hypothetical and inauthentic images of social and discursive processes. ${ }^{67}$

Linking Şentürk's observation with the above, where does that leave us? Clifford's observation that the study of "informal social network analysis" has remained the "basic thrust line of history", mutatis mutandis, implies that we have neglected diachronicity. Analyzing a network is first and foremost a question of reconstructing and interpreting a network at a particular point of time. Indeed, in his state-of-the-art on Mamluk network analyses, Sievert acknowledges this. Introducing a thoughtful presentation of various properties of networks (such as density, direction, and centrality, none of which imply a diachronic dimension by definition), Sievert writes that:

Even proof of existence (of verifiable connections) alone does not necessarily support far-reaching conclusions. Besides, evidence of a relationship usually represents a snapshot in time, while its content, strength and other characteristics are subject to change. ${ }^{68}$

So it seems that while we know that struggles over the sultanate were fought not just over the late sultan's deathbed, we have still found it hard to accommodate the long and protracted nature of these struggles into informal network analyses. By consequence, we have tended to explain away the outcome of these struggles in terms other than of sequential events. As diachronicity was pushed aside by synchronicity, sequentiality saw itself outmaneuvered by what I refer to in this chapter-perhaps somewhat flippantly-as "historical contingency". ${ }^{69}$ What I mean to convey here is the fact that we deem the

$67 \quad I b i d$. Starting from the "often-invoked but rarely examined declaration that 'history matters", Pierson (Politics in Time, 2) calls for us to place politics back in time, and to work with "'moving pictures' rather than snapshots". For a good introduction to institutional path dependency, see Schreyögg \& Sydow, "Understanding Institutional and Organizational Path Dependencies".

68 Sievert, "Family, Friend or Foe?", 86 (italics mine).

69 This "contingency" is not to be misunderstood as "vicissitudes of fates", which incidentally is the way in which Ibn Taghrībirdī referred to the endless reshuffling of offices (taqallubāt al-dahr, Nujūm, 7: 236). A "contingent event" is not an event which occurs as arbitrarily as a roll of the dice. Rather, it is an event which occurs "subject to unseen effects" (compare, e.g., the definition as found in Merriam-Webster). Said otherwise, the very fact that events are considered first and foremost as being determined by informal and ad hoc featuresfeatures that are knowable only imperfectly and ex post facto to a large extent- this is what makes them "contingent". Compare to Clifford's observation regarding Chamberlain's work (“Ubi sumus?", 6o): “(This) remains fundamentally indebted to Bourdieu's 
outcome of struggles to be determined by the agents' informal and ad hoc features first and foremost, while the institutional career track that brought them there is mostly left invalidated.

In my view, as these consequences feed back into the initial assumptions, a circularity is set off and offices and career tracks have a hard time escaping from this. While, at the onset, institutions may be considered only less (but thus still somewhat) important, they are easily caught up in this circularity and tend to recede to the background ever more, indeed eventually to vanishing point. ${ }^{70}$ This runaway logic thus leaves us with institutions that are little more than a wardrobe of khil'as, ever more fancifully embroidered yet ever less empowering. Along the same lines, career tracks are seen as those long lists of offices in the entries of biographical dictionaries, useful to us only when slicing up history in synchronic snapshots and when identifying the main players there and then.

Let me now return to the particular phrase that opened this chapter, Ibn Taghrïbirdi's fighayr waqtihi. As demonstrated in the previous section, it would seem that Jaqmaq's victory over Qurqumās makes sense as being ex officio, for he, not Qurqumās, was the atābak. Hence, we could read Ibn Taghrïbirdī's "wrong time" as referring a point in Qurqumās' career: as Qurqumās was not the atäbak, his run for sultan must have been "institutionally premature". However, I have also maintained that - even in spite of Ayalon's statement and in the face of empirical evidence - we are reluctant to take the argument that far. Whence the reluctance? In light of the foregoing, I argue that this reluctance stems from our understanding of fourteenth-century socio-political culture, with its runaway logic of extra-institutionalism and contingency which spills over into our understanding of the fifteenth. Let me demonstrate this.

basic understanding of social structures as a product of radically contingent action by self-reflective individuals rather than an 'institutionalized call to order"'.

Neither my critique nor my subsequent call for sequentiality implicates a teleological reading of history, as I espouse the "global contingency" as described by Sewell Jr ( Logics of History, chapter 3, "Three Temporalities. Toward an Eventful Sociology" 81-123, here 102: "The eventful conception of temporality, then, assumes that social relations are characterized by path dependency, temporally heterogeneous causalities, and global contingency".)

70 In relation to the fourteenth century, a good case in point would be Van Steenbergen's "The Mamluk Sultanate as a Military Patronage State". Building on the work by Hodgson and Chamberlain, Van Steenbergen rethinks the Mamluk Sultanate as a military patronage state, which "eschews the idea of the polity as a unitary state and an institution that existed autonomously of its ruling elite", instead seeing "the state or polity as no more than a fragile 'collection of powerful households kept in check by the most powerful among them"' (194). 
Thus far, I have been talking about the "institutional", which it will be recalled is a shorthand for "formal political institutional". Conceptualizing this "institutional" along the dichotomous line of thought relating to the fourteenth century, it makes sense to think of it as the "formal" side of the coin, as opposed to the extra-institutional as its "informal" side. Subsequently one can think of the institutional as the "formalization of the informal". ${ }^{71}$ Tenures, titles, particular types of sartorial privileges, seating or standing position in assemblies or parades, and iqt $\bar{a} \bar{c}$ classes are thus recast as ex post facto "formalizations" of a priori acquired informal power. ${ }^{72}$ Consequently, it becomes increasingly difficult to think of institutions as strong rather than weak, as empowering in their own right, instead of merely reflections of power. Likewise, careers are reduced to a progression of historical contingencies, constrained only informally, and not (also) as a formally constrained sequence of events. Hence, we surely cannot explain the fact that atābak Jaqmaq makes it to sultan (also) from a formal and sequential perspective as something ex officio (that is, on account of his last pre-sultanic office and of the institutional career track that brought him there). Rather, we can (only) do so from an informal and a contingent perspective as something ex virtute (that is, by the fact that, apparently, there and then, it was he who happened to have the strongest informal capital configuration, due to a larger network, more money to spend, a greater charisma, etc.). Jaqmaq's victory must be seen as the latest of a progression of historical contingencies, not as the last of a formally constrained sequence of events. At best, his atābakiyya is still considered an "advantage" (as under-defined as this may be); at worst, it is not even considered, and atābak Jaqmaq is left to emerge victoriously "from a coterie of contenders". ${ }^{73}$

Concluding, let me stress that I see no particular reason to make a case for re-evaluating our understanding of the fourteenth century. Neither do I question the validity of network analysis as a useful tool to map a concept which mattered a great deal, namely social capital. I merely argue that we should not

71 For a similar use of a șüra vs. mánā ("appearance" vs. "reality") dichotomy, this time informed by an Ottoman poem and applied to Ottoman-Mamluk diplomacy and to the history of diplomatic protocol in general, see D'hulster, "Fixed Rules to a Changing Game?" To return to the Romans once more, compare with Kunkel \& Wittman, Staatsordnung und Staatspraxis der römischen Republik.

72 Compare to Chamberlain, for example, who thinks of the institutional as monetized honors in reward of political dexterity. Institutions are thus ex post facto translations of a priori established power relations.

73 It is quite telling, for example, that a monograph on the last two great Mamluk sultans, Qāytbāy and Qānșūh, fails to record their last pre-sultanic office. All one learns is that they were amirs of 100 (Petry, Protectors or Praetorians, 14, 20). 
allow our understanding of the fifteenth century to be caught up in this runaway logic, as what happened to institutions and career tracks in the preceding paragraphs, and, indeed, as what happens to us, when we-in the face of empirical evidence-are reluctant to drop the inverted commas of the "rule". However founded and cautious the basic assumptions regarding the fourteenth century may be, they trigger a circularity, and it becomes ever more difficult for analyses of fifteenth-century institutions and careers to escape from this, thereby making it ever more difficult for us to detect possible institutional or sequential changes.

Towards the Atäbakiyya as a Rule in the Making? "Endowing messy past realities with new meanings"74

In the first section, I have dealt with the question as to why Ayalon considered the atäbakiyya as a key to the sultanate. Next I answered the question as to why we are reluctant to call this a rule proper, by exploring how we have come to think of the road to the citadel as a "historically contingent progression of events", rather than as an "institutionally constrained sequence of events". We are therefore now in a much better position to appreciate the institutional reading of the first section, and to understand exactly what such a reading offers. It infuses our understanding of fifteenth-century Mamluk socio-political culture with an explicit institutional and sequential dimension, thus allowing institutions and careers to break free from the circularity argued above. As such, it enables us to re-think these as (at least potentially) strong and (at least partially) institutionally constrained. It also lets us yield to Ayalon's statement and to the empirical evidence that informed this, and thus - at last! - to drop the inverted commas of the "rule". Hence, in this section, I start by discussing in more detail what it takes for offices to be "strong" and for "careers" to be institutionally constrained. Next, I ponder the consequences of that understanding for the wider framework of institutionalization and state (trans)formation in the Sultanate of Cairo and beyond.

As one of the few examples of genuine social network studies of crosstemporal structures, Şentürk, quoted above, refers to Harrison White's 1970 monograph, Chains of Opportunity, System Models of Mobility in Organizations. In his work, to which the present chapter owes more than its title, White analyzed the structure of opportunity in large organizations as "chains of upward moves sequentially ordered in time". In its own idiosyncratic way, the

74 Paraphrasing Algazi, “Comparing Medieval Institutions”, 12. 
institutional reading offered here does precisely that. By infusing the sequential approach, much undervalued in social network studies, this reading allows us to rethink the "road to the citadel" and Mamluk careers in more novel terms as "chains of upward moves". Atābak İnāl becoming sultan is now no longer the historically contingent outcome of a power struggle, but rather the last move in a long social sequential trajectory. A sequential perspective reveals that the battle over the sultanate following Jaqmaq's death in 857 did not start over Jaqmaq's deathbed but was concluded over it! In other words, it points to the fact that Īnāl was already well on his way, indeed, well-nigh unstoppable, in reaching the citadel, already ten years before, when sultan Jaqmaq appointed him atābak al-'asākir.

Obviously, "re-cognizing" Mamluk careers as upward moves sequentially ordered in time rather than as historically contingent events is one thing. Rethinking these moves as actually institutionally constrained is yet another. At this point, institutions may still be thought of as "weak", that is as little more than rather faltering reflections of the ups and downs of individuals' informal capital. What we have established thus far is that Īnāl's atābakiyya and subsequent sultanate are part of a long chain of events, not that his atäbakiyya was a form of capital in its own right, which, in tandem with other types of capital, propelled him towards the sultanate. While the old saying that "it is the man who makes the office honourable" may still hold true, in order to retain "institutional constraints" as a meaningful analytical tool we need offices that, in their turn, "dignify the man". For this approach to work, we need offices that are more than just names, or ever more fanciful khil'as, larger iqțās and better seats at the sultan's majlis, which all, in the end, are reducible to ex post facto reflections of social mobility. In order to retain these constraints we need "strong" offices: offices that do not just "reflect social mobility, but determine its velocities as well". ${ }^{75}$ In short, what we are looking for are offices that come with their own, new sort of capital, still inter-convertible with other, informal

75 Hudson \& Rodríguez, "Preface", xi. In other words, offices that not just "communicate" (or "say", "reproduce", "express", etc.) an individual's existing informal capital configuration, but "perform" it (or "do", "produce", "empower", etc.). Compare to Bodenhorn \& vom Bruck's discussion of the anthropology of names and naming ("Entangled Histories", 4-5); and Searle, who argued that "the essential role of human institutions and the purpose of having institutions is not to constrain people as such, but, rather, to create new sorts of power relations. Human institutions are, above all, enabling, because they create power, but it is a special kind of power. It is the power that is marked by such terms as: rights, duties, obligations, authorizations, permissions, empowerments, requirements, and certifications" ("What is an Institution?" Journal of Institutional Economics (2005): 1-22, here p. 10, quoted in Humfress, "Institutionalisation between Theory and Practice", 27). 
types of capital, yet not reducible to these. For lack of a better term, I suggest we call this new type of capital "institutional capital". ${ }^{76}$

It is important to realize that in order to do so, this actually requires us to part with the metaphor of Mamluk socio-political culture as a two-sided coin. Rather than a one-dimensional dichotomous pair, socio-political culture is recast here as a multi-dimensional configuration of social, cultural, symbolic, economic and institutional capital, all of which are interrelated and interconvertible, yet not reducible to one another. This novel conceptualization provides us with a plausible way to come to terms with a wide array of episodes, both moments that are "institutionally uncomplicated" (such as Jaqmaq's successful transition from atābak to sultan) as well as "institutionally complicated" incidents (such as atābak Timurbughā's failed sultanate, non-atābak Barsbāy's successful sultanate, or the atābakiyya of sultan İnāl's son). The novel conceptualization does not claim that Jaqmaq made it sultan only because of his atābakiyya. All that it maintains is that, in sum total, Jaqmaq was the strongest man, and that the atäbakiyya may have been what gave him the edge over his other competitors. For all we know, Qurqumās may have been stronger than Jaqmaq economically, socially, culturally or symbolically. Yet, in total, the balance tipped in favor of Jaqmaq, and it might have been his institutional capital that made the difference. As for Barsbāy, as he had not been sultan he might be thought of as institutionally weak. Yet, he made it to sultan after all, because the sum total of his capital outweighed that of his competitors. For all we know, he may have been a better networker or a more charismatic individual than the atābak. How can we explain Timurbughā's smooth move from atābak to sultan, followed by his quick downfall at the hands of Qāytbāy? Initially, what gave Timurbughā the edge over all other competitors and what gained him the sultanate might have been his institutional capital, that is the simple fact that he was the previous sultan's atäbak. His untimely downfall at the hands of Qāytbāy could then be explained by the fact that, Timurbughā was fairly weak in terms of other types of capital, or at least weaker than Qāytbāy. By being appointed by Timurbughā as his atābak, Qāytbāy's institutional capital boosted, now tipping the total balance in his favor. Finally, we

76 Compare to Bourdieu's concept of "capital étatique", referring to the elaboration of bureaucratic institutions and the channeling of resources and access to power through these institutions, which become divorced from their original dependence on the person of the ruler. Bourdieu coined the term, yet left it to others to turn this into an applicable analytical tool. For one such exercise, hardly relevant in the given context, see, e.g., Casey, "Defining Political Capital". 
can now also re-evaluate Innāl's appointment of his son as atābak. Whatever the father-sultan hoped to achieve, clearly this was not something that he thought he could achieve in a different way. Indeed, he must have thought of the atäbakiyya as a strong office: an office that not only gave its holder a financial (and thus a social, cultural...) boost, but that added something irreducible to other types of capital.

This chapter does not make the sweeping claim that institutions "ruled". Instead, it maintains more modestly, that institutions started to "matter" in the fifteenth century in novel ways. Even so, if we come from the mindset that is informed first and foremost by synchronically oriented informal network analyses, thinking about Mamluk offices in terms of "institutional capital" may require no less than a "leap of faith". Obviously, this is no great surprise. As Hugh Heclo rightfully observed, "to think institutionally is to stretch your horizon backwards and forwards so that the shadows of both past and future lengthen into the present". ${ }^{77}$ In other words, this leap may be less daunting when we realize that more than anything else, we are really talking about processes of institutionalization. We should be looking not for institutions per se but for "fragile, emerging and wannabe-institutions",78 not for codified rules but for practices of the "actual making of institutions (and of the) construction of their meaning". ${ }^{79}$ As Gadi Algazi puts it:

(Institutional processes) occur only partly 'in real time'; a significant part of the process happens ex post facto, as messy past realities are endowed with new meanings, as improvised practices are formalized and regularized after the fact in ways that may not have been possible within their actual, contingent contexts. ${ }^{80}$

When looking for an apt term to capture this process of institutionalization, it is worth considering a recent article, written together with Jo Van Steenbergen and Patrick Wing, which posited a remarkably similar hypothesis, albeit along very different lines. In that article, we return to the concept of "Mamlukization", as it was coined by Ulrich Haarmann to refer to the "long process of the erosion of the non-Mamluk elites' power to the benefit of the sultan and the royal mamlüks

77 Heclo, On thinking institutionally (Oxford University Press, 2008), p. 109, quoted in Humfress "Institutionalisation between Theory and Practice", 29.

78 Algazi, “Comparing Medieval Institutions", 15.

79 Ibid., 14.

$80 \quad$ Ibid., 12. 
who underpinned the system". ${ }^{81}$ While this process of "Mamlukization" appears most saliently in the position of the sultan, we have hypothesized that it is part of a broader development of a "cultural (re)production of a 'truly' Mamluk state", where identities, memories and repertoires of mamlük-ness acquired 'statist' meaning and value, referring now to powerful socio-political tools for distinction and entitlement, rather than to household bonding and military organization. ${ }^{82}$ As part of this development, loyalties increasingly came "to reside with the institutional order itself, rather than with a particular sultan's household". ${ }^{33}$ While Mamluks were still very much mamlūk-somebody's mamlük, somebody's khushdāsh, somebody's ustādh, loyal to and bound by personal networks - at the same time, they were turning "Mamluk" as well, that is, committed to a higher institutional order of Mamluk-ness. ${ }^{84}$ Or in other words-double-entendre intended!-mamlūk was being capitalized as Mamluk.

Rephrasing these re-centered "loyalties" along the lines set out in this chapter, one could state that Mamluk careers gradually escaped from the logic of the sultan's household and moved towards a new logic of the "Mamluk house of state". ${ }^{85}$ No longer (only) determined by historically contingent patronage, Mamluk careers were in the process of turning into cursus honorum, a sequence of (partially) institutionally constrained events. What was Înāl doing through the "mamlūkizing" appointment of his son as atābak? He was bending

81 Haarmann, "The Mamluk System of Rule", 22, quoted in Van Steenbergen, Wing \& D'hulster, "The Mamlukisation of the Mamluk Sultanate? Part I" and "Part II", here "Part II", 565 .

$82 \quad$ Ibid.

83 Ibid.

84 Apart from Bourdieu, compare this to Weber's concept of "sanctification of acquired rights" ("Social strata, privileged through existing political, social, and economic orders.... wish to see their positions transformed from purely factual power relations into a cosmos of acquired rights, and to know that they are thus sanctified" (Wirtschaft und Gesellschaft) quoted in Wacquant, "On the Tracks of Symbolic Power", 1), and to Schreyögg \& Sydow's take on institutionalisation as a transformative and self-reinforcing process ("the evolvement and stabilization of social hierarchies have been explained by self-reinforcing processes (...). Status hierarchies, for instance, once established, unfold self-reinforcing dynamics because the status of individuals determines how other individuals perceive and evaluate their behavior"; "the process starts with agency, an intended individual or collective action, which is enabled or constrained by structures and triggers reactions that transform the process into a dynamic reaction system beyond individual intentions") ("Understanding Institutional and Organizational Path Dependencies", 4, 8).

85 Paraphrasing Bourdieu's "From the King's House to the Reason of State". Compare to Bourdieu, "Rethinking the State" (especially "From Honor to Cursus Honorum", 10-12). 
the extra-personal logic to his advantage, in order to pursue his own household logic. What about those appointments and promotions that are referred to in the sources as duf'atan wähidatan, "in one jump"?86 For example, when an amir of 100 is said to be appointed as hājib hujjāb "in one jump", how else can we understand this than by the fact that, apparently, there was an extrapersonal, Mamluk logic, against which a personal, mamlūk logic could be weighed...

\section{$5 \quad$ On the Road Again...}

By way of conclusion, let me return one last time to Ibn Taghribirdī's ghayr waqtihi, "the wrong time". Are we now in a position to decide what "time" the author was referring to? Did he-or should we—think of Qurqumās as as valid a candidate for the sultanate as Jaqmaq was, yet a strategist much worse? Or did he rather think of Qurqumās as institutionally premature for the sultanate, as he was not an atābak? Concluding the previous section, I have referred to the expression duf'atan wāhidatan, and I have highlighted its important implication that the "road to the citadel" was (becoming) institutionally constrained. In this light, we might see Qurqumās as being institutionally unfit for the sultanate. Yet, the crux of the matter here might be the fact that the expression duf'atan wāhidatan is a double-edged sword. For the phrase also implies something else: that these institutional constraints could still be overruled personally. Perhaps no longer subject to personal whims alone, the road to the citadel was still very much open to personal interventions. It is in this second light that we might still think of Qurqumās' failed run as a historical contingency. Although it is hard to substantiate, it is tempting to read the tension expressed by the double-edged sword of duf'atan wähidatan in one of Ibn Taghrïbirdì's statements. Following the enumeration of the main office-holders of the year 866/1461-1462, the annalist's conventional opening of a new year, the author concludes: "We have mentioned them (...) according to their station and their seat at the sultan's majlis (bi-hisb manāzilihim wa-julūsihim bi-majlis alsulțān)".87 I cannot tell what we should make of the pair of manzil and julūs, but this does suggest that there is more than just one velocity to Mamluk careers, one institutional (cursus honorum) and one extra-institutional (social mobility).

$86 \quad$ See the excursus for more details.

87 Ibn Taghrībirdī, Hawādith, 411. 
To reiterate, this chapter does not posit that institutions "ruled", let alone that these "overruled" extra-institutional aspects. Rather, it maintains that institutional constraints "started to matter". As a working hypothesis, the chapter posits a process of "Mamlukization", which above all involves institutional constraints in the making. Elaborating on the metaphor of the "Mamluk house of state", the chapter sees this as an old house under reconstruction more than anything else. The process in question is a gradual, on-going and imperfect refurbishing, "Mamluk style" this time, of the sultan's household. It is eclectic and erratic, with rooms being added, restyled or neglected. One roomprobably in the back-is taken up by the Abbasid caliph. In another room, we find a fairly well kept Barqūqid vestiary, while next to it there is a dusty Qalāwūnid larder. ${ }^{88}$ On a more moderate scale, this chapter hopes to have revealed and problematized some of the assumptions that continue to inform Mamluk socio-political studies, and to have highlighted the potential inherent in explicitly infusing these with an institutional and diachronic dimension, alongside (and thus not at the expense of) the extra-institutional and networks. Wang and Polillo perhaps give the best description of what this future research agenda might look like:

The relationship between informal and formal power in organizations is an unceasingly fascinating research topic. Unfortunately, the current artificial separation between network analysis and organization studies as two subfields has slowed the study of the cross-fertilization of power resided in networks and organization. (...) The question then becomes how positional power that derives from structural positions in exchange networks differs from the one that is embedded in organization hierarchies. ${ }^{89}$

In a way, this chapter is as much about Mamluks as it is about Mamlukologists, or-putting this more modestly—as much about Qurqumās and Jaqmaq as it is about the present author. For the Mamluks, the road to the citadel must have been a long and winding one, both empowering and constrained ever more as they advanced. So too is this road for us today, as we are trying to endow Mamluk "messy past realities with new meanings". And so we are on the road again....

88 This metaphor draws its inspiration from Van Steenbergen, “Mamlukisation' between social theory and social practice", passim.

89 Wang \& Polillo, "Power in Organizational Society: Macro, Meso and Micro", 56. 


\section{AN EXCURSUS ON THE ATĀBAKIYYA: OPPORTUNITIES SEIZED, ENHANCED, MISSED}

While the "road to the atäbakiyya" itself, with its various bifurcations and dead ends, falls outside the scope of this chapter, three observations merit a brief discussion. Undoubtedly, more - but probably not that much more ${ }^{90}$ - could be said about the fifteenth-century atäbakiyya itself, but that will have to be saved for another occasion.

First, how did one become atābak? In brief, while the atābakiyya appears to have put one in the institutional "pole position" when running for sultan, the way to gain the atäbakiyya itself seems to have been somewhat more "open institutionally". Of all 28 atäbaks attested for our period, 12 moved there from the office of amir siläh, 5 from that of amir majlis and 2 from that of amìr àkhür kabir. An institutional reading thus suggests that these three offices were the most common starting position when running for atābak, and indeed this new "rule" is confirmed by a comment in the chronicles. There were only two dawādārs who made it to the office of atäbak duf'atan wähidatan, "in one jump": Barsbāy, whose career, as said before, truly skyrocketed from an institutional perspective; and Īnāl. When the latter moved from dawādār to atābak "in one jump", thus skipping the step of amìr siläh, amìr majlis or amìr ākhür kabìr, Ibn Taghrībirdī stated:

Because of the appointment of (dawādār) Ināl to the atābakiyya, there was a lot of backbiting (kaläm kathir fi-l-bātin), as the sultan had advanced him to the detriment of (qaddamahu 'alā) the amīr silāh Timrāz al-Qurmishī, the amìr majlis Jarbāsh al-Karīmī and the amìr ākhūr Qarāqujā, all of them Zāhirīya Barqūqìya, even though one was (normally) transferred to the office of atābak from (one of) their offices, and not from the office of dawādār (wa-wazāàifuhum aydan taqtadì l-naql ilā alatābakiyya bi-khilāa al-dawādāriyya) ${ }^{91}$

9o It comes as little surprise that the major drawback to probing more closely into the atäbakiyya is the sultan-centeredness of the chronicles. Compare, e.g., in UGent's $\mathrm{MP}_{3}$ database the number of sultan-related interactions recorded (4,307 out of a total of 11,471) with that of atābak-related interactions (a meager 325!). The $n \bar{a} i b$ of Damascus fares slightly better than the atābak (396 interactions), the dawādār slightly worse (315 interactions).

91 Ibn Taghrībirdī, Hawādith, 86-87. See also Ibn Taghrībirdī, Nujūm, 7: 424: "He was the dawādār until al-Zāhir (Jaqmaq) transferred him to the position of atābak al-'asākir in the Egyptian domains in one jump (duf'atan wāhidatan)". Apart from this, quite some other career moves were referred to as surprisingly duf'atan wähidatan, including the 
This quotation proves that, even below the level of the atäbakiyya, there were institutional constraints on Mamluk career trajectories. Clearly, these trajectories were not as fully contingent as commonly assumed, but were institutionally constrained in some way, and to some extent. The cumbersome exercise of rewriting a large number of Mamluk careers into office sequences, from julbān upwards, might well yield more such constraints. This exercise, however, will not be taken up here. As said before, this chapter focuses on the road to the citadel's higher end only.

As a second, non-institutional excursus, it is interesting to note that many of the atäbaks were related to sultans' households through marriage: ${ }^{92}$ Altunbughā al-Qurmushī, Jānibak al-Ṣūfī, Baybughā al-Muẓaffarī, Qujaq, Īnāl al-Jakamī, Qurqumās al-Sha'bānī, Aqbughā al-Timrāzī, Yashbak al-Sūdūnī, and Jarbāsh Kurd all displayed such a marital tie, being married either to a (late) sultan's daughter, umm walad or widow. ${ }^{93}$ This is an interesting observation, for it allows us to tentatively answer a question we have left open elsewhere. In a 2013 article on the sultans' marriages, Van Steenbergen and myself demonstrated that "new" sultans were often "married into" the household of late sultans. Recognizing this as a deliberate marriage policy, we have argued that new sultans forged these marital ties to a late sultan first and foremost in order to boost their symbolic capital. If not related to a previous sultan by blood, then they would at least be linked by marital ties; if you could not be the late sultan's son, then at least be his in-law! ${ }^{94}$ As the exact dates of these marriages are mostly left unrecorded, we were unable to establish whether such marital ties were forged prior to each new sultan's accession (and hence could be considered preparatory maneuvers), or forged following their accession (and hence should be considered consolidating ones). Given the fact that also those atäbaks who didn't make it to sultan were often married into a sultan's family, we might infer that also those who did make it to sultan had forged such

move from amìr 5 to amìr 100, from atābak of Țarābulus to $n \bar{a} i b$ of Șafad, from nā'ib of

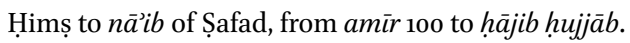

92 This same observation holds for the two nizām al-mulks who made it to sultan: Tatar, who was married to Sacādat, a wife of sultan Shaykh and the mother of the latter's sultan-son, Aḥmad; and Barsbāy, who was married to Fāțima, a daughter of sultan Ṭațar and a sister of the latter's sultan-son Muhammad.

93 Turning mamlūks into "royalty", these marriages could be called "dynasticizing" or "royalizing" and reflect a move opposite to Īnāl's "mamlūkizing" appointment of his nonmamlūk son as atābak.

94 D'hulster \& Van Steenbergen, "Family Matters". See especially p. 76, where we already called for a consideration of the marital ties of those atābaks who didn't make it to sultan. 
marital ties prior to accession. In other words, marriages into sultans' households were preparatory rather than consolidating maneuvers. ${ }^{95}$

Finally, given the importance of the atābakiyya, it is interesting to see what happened to those 20 (out of 28) atābaks who did not make it to sultan. Surely, they were unlikely to have given up such a prized office? Of those who did not make it, 7 died in function or were discharged due to high age or illness, 4 were appointed as $n \bar{a} i b$ of Damascus (once of Aleppo), and the remaining ones rebelled against the sultan and were consequently discharged. So it seems that the careers of atābaks hint at the office's importance: most commonly, atābaks either succeed the late sultan or, in case the sultan outlives them, die in office; or, unwilling to bide their time, revolt against the sultan and are subsequently removed. ${ }^{96}$

95 It should be pointed out that there is nothing new in the fact itself that atābaks, as guardians of the sultans' sons, sometimes married the widows of their late master and thus the mothers of their pupils. Starting out as "guardians" of sultans' sons (see above for the historical roots of the atābakiyya), these atābaks thus became "stepfathers" to these sons as well (this translation is somewhat flippant, yet more in line with the word's etymology). Think for example of the marriage of Tughtakinn of Damascus, atābak of Tutush II and Baqtash, sons of the Seljuq ruler Duqaq, to the latter's widow (Cahen, "Atabak", 731).

96 For more details, see the right column in the table at the end. 
TABLE 3.1 Cairo Sultans and their atābaks

\begin{tabular}{llll}
\hline Period of rule & Sultan (age) & Son & Nizāam al-mulk \\
\hline$-1 / 8 / 815$ & al-Musta'īn & $/$ & Shaykh \\
$1 / 8 / 815^{-9 / 1 / 824}$ & Shaykh & Aḥmad & $/$
\end{tabular}

9/1/824-29/8/824 Aḥmad b. Shaykh (2) / Ṭațar

29/8/824-2/12/824 Ṭațar Muhammad /
2/12/824-8/4/825 Muhammad b. Țațar(10) / Jānibakm

8/4/825-13/12/841 Barsbāy $\quad$ Yūsuf

$\begin{array}{llll}13 / 12 / 841-19 / 3 / 842 & \text { Yūsuf b. Barsbāy }(14) & / & \text { Jaqmaqy }^{y} \\ 19 / 3 / 842-21 / 1 / 857 & \text { Jaqmaq } & \text { 'Uthmān } & /\end{array}$

21/1/857-7/3/857 'Uthmān b. Jaq. (>10) / / (?) 


\begin{tabular}{|c|c|c|}
\hline Tenure & Atābak & Comments \\
\hline$-1 / 8 / 815$ & Shayk ${ }^{\mathbf{b}}$ & $\rightarrow$ Sultan \\
\hline $8 / 8 / 815^{-2 / 9 / 817}$ & Yilbughāc & Dies \\
\hline $8 / 9 / 817-7 / 5 / 818$ & Alțunbughā 'Uthmān̄̄ ${ }^{\mathrm{d}}$ & $\rightarrow N a \bar{a} i b$ Damascus \\
\hline $7 / 5 / 818-6 / 818$ & Qāंnibāye & Conflict with Shaykh \\
\hline $27 / 6 / 818-821$ & Alțunbughā Qurmushīi ${ }^{\mathrm{f}}$ & Replaced by sultan's son \\
\hline $821-15 / 6 / 823$ & Ibrāhīm b. Shaykhg & Dies \\
\hline $15 / 6 / 823-9 / 1 / 824$ & Alțunbughā Qurmushīh & $\rightarrow$ Atābak \\
\hline $9 / 1 / 824-9 / 3 / 824$ & Alțunbughā Qurmushīj & Conflict with Țațar \\
\hline $9 / 3 / 824-16 / 5 / 824$ & Tanibak Miyiq ${ }^{\mathrm{k}}$ & $\rightarrow N \bar{a} i b$ Damascus \\
\hline $16 / 5 / 824-29 / 8 / 824$ & Jānibak & $\rightarrow$ Atābak \\
\hline $29 / 8 / 824-2 / 12 / 824$ & Jānibak & $\rightarrow$ Atābak + nizām al-mulk \\
\hline $2 / 12 / 824-10 / 12 / 824$ & Jānibakn & Conflict with Barsbāy \\
\hline $16 / 12 / 824-10 / 2 / 825$ & Țarabāyp & Replaced by Barsbāy? \\
\hline $10 / 2 / 824-6 / 4 / 825$ & Vacant $^{\mathrm{q}}$ & \\
\hline $9 / 4 / 825-4 / 11 / 827$ & Baybughār & Conflict with Barsbāy \\
\hline $4 / 11 / 827-12 / 9 / 829$ & Qujaq $^{s}$ & Dies \\
\hline $12 / 9 / 829-5 / 6 / 831$ & Yashbak Sāqīt & Dies \\
\hline $5 / 6 / 831-22 / 7 / 835$ & Jārquṭlū ${ }^{\mathrm{v}}$ & $\rightarrow N a \bar{i} i b$ Damascus \\
\hline $22 / 7 / 835^{-19 / 3 / 837}$ & Sūdūn ${ }^{u}$ & Sick \\
\hline $19 / 3 / 837-29 / 7 / 837$ & Vacant & \\
\hline $29 / 7 / 837-8 / 3 / 839$ & Īnāl al-Jakamīw & $\rightarrow N \bar{a} i b$ Aleppo \\
\hline $8 / 3 / 839-13 / 12 / 841$ & Jaqmaq $^{x}$ & $\rightarrow$ Atābak \\
\hline $13 / 12 / 841-19 / 3 / 842$ & Jaqmaq $^{\mathbf{z}}$ & $\rightarrow$ Sultan \\
\hline $20 / 3 / 842-7 / 4 / 842$ & Qurqumās aa & Conflict with Jaqmaq \\
\hline $7 / 4 / 842-23 / 9 / 842$ & Āqbughāab & $\rightarrow N \bar{a} i b$ Damascus \\
\hline $23 / 9 / 842-10 / 10 / 842$ & Vacant & \\
\hline $10 / 10 / 842-847$ & Yashbak Sūdūnīiac & Dies \\
\hline $3 / 8 / 847-21 / 1 / 857$ & Īnālad & $\rightarrow$ Atābak (or 'Uthmān?ae) \\
\hline $21 / 1 / 857-7 / 3 / 857$ & Īnālaf & $\rightarrow$ Sultan \\
\hline
\end{tabular}


TABLE 3.1 Cairo Sultans and their atābaks (cont.)

\begin{tabular}{llll}
\hline Period of rule & Sultan (age) & Son & Nizāmal-mulk
\end{tabular}

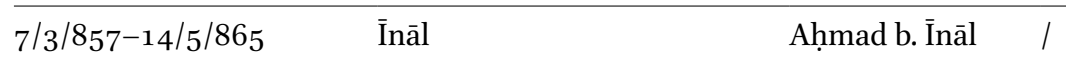

$\begin{array}{ll}14 / 5 / 865^{-19} / 9 / 865 & \text { Aḥmad b. Īnāl (30) } \\ 19 / 9 / 865^{-10} / 3 / 872 & \text { Khushqadam }\end{array}$

10/3/872-7/5/872 Yilbāy

7/5/872-5/7/872 Timurbughā

5/7/872- Q Qāytbāy

\footnotetext{
a Al-'Ayn̄̄, 'Iqd, 1: 144.

b Ibn Taghrībirdī, Nujūm, 6: 323-324.

c Al-Maqrīzì, Sulūk, 4: 245-246; al-'Aynī, 'Iqd, 1: 215-216.

d Al-Maqrīzì, Sulūk, 4: 284; al-'Aynī, Iqd, 1: 229.

e Al-Maqrīzì, Sulūk, 4: 319, 325 .

f Ibid., 325, 477, 517.

g Ibid:; Ibn Taghrībirdī, Nujūm, 6: 476 .

h Ibid., 546-547. The sources are somewhat blurred, but it appears that sultan Shaykh had first replaced atābak Alțunbughā with his son, Ibrāhīm (during which time Alțunbughā held the title of amīr kabīr, a title often going hand in hand with that of atābak), and then reappointed him, following Ibrāhīm's premature death.

i Al-Maqrīzì, Sulūk, 4: 565, 582. See the discussion in Section 2.

j. Ibid.; Ibn Taghrībirdi ${ }_{s}$ Nujūm, 6: 546-547.

k Al-Maqrīzī, Sulūk, 4: 572-573, 578-579.

l Ibid., 4: 578-579.

m Ibn Taghrībirdī, Nujūm, 6: 531-532.

n Ibn Iyās, Badā'i al-Zuhūr, 2: 76-77.

o Al-Maqrīzì, Sulūk, 4: 593; Ibn Iyās, Badā’i al-Zuhūr, 2: 79-8o. See the discussion in Section 2.

p Ibn Taghrībirdī, Nujūm, 6: 531-532; al-Ṣayrafī, Nuzhat al-Nufūs, 2: $5^{26}$.

q Al-'Aynī, 'Iqd, 2: 181.

r Ibid.,181; Ibn Taghrībirdī, Manhal, 3: 489-492.

s Al-'Aynī, Iqd, 2: 229, 300.

t Ibid., 3oo; al-Maqrīzì, Sulūk, 4: 773 .
} 


\begin{tabular}{|c|c|c|}
\hline Tenure & Atābak & Comments \\
\hline $9 / 3 / 857-11 / 3 / 857$ & Aḥmad b. Īnālag & Contested office \\
\hline $11 / 3 / 857-24 / 11 / 862$ & Tanibak Ẓāhirīah & Dies \\
\hline $27 / 11 / 862-15 / 5 / 865$ & Aḥmad b. Īnālai & $\begin{array}{l}\rightarrow \text { Sultan } \\
\text { (contested office) }\end{array}$ \\
\hline $15 / 5 / 865^{-19 / 9 / 865}$ & Khushqadam $^{\mathrm{aj}}$ & $\rightarrow$ Sultan \\
\hline $19 / 9 / 865^{-18 / 9 / 869}$ & Jarbāshak $^{\text {ak }}$ & Banished \\
\hline $20 / 9 / 869-11 / 2 / 871$ & Qānimal & Dies \\
\hline $18 / 2 / 871-10 / 3 / 872$ & Yilbāyam & $\rightarrow$ Sultan \\
\hline $10 / 3 / 872-7 / 5 / 872$ & Timurbughāan & $\rightarrow$ Sultan \\
\hline $7 / 5 / 872-5 / 7 / 872$ & Qāytbāy ao & $\rightarrow$ Sultan \\
\hline
\end{tabular}

v Ibid, 773,868 .

u Ibid., 868, 906.

w Al-Ṣayrafì, Nuzhat al-Nufūs, 3: 282-283; al-Maqrīzī, Sulūk, 4: 958.

$\mathrm{x}$ Ibid., 958.

y Ibn Taghrībirdī, Manhal, 4: 279 .

z Ibid., Manhal, 9: 58-59.

aa Al-'Aynī, 'Iqd, 2: 516; al-Ṣayrafì, Nuzhat al-Nufūs, 4: 37.

ab Al-Maqrīzì, Sulūk, 4: 1096, 1112.

ac Ibid., 1122-1123; Ibn Taghrïbirdī, Nujūm, 7: 422-424.

ad Ibid., 422-424.

ae See the discussion in Section 2.

af Ibid., 420.

ag Ibid., 425-426; Ibn Taghrībirdī, Hawādith, 318. See the discussion in Section 2.

ah Ibn Taghrïbirdī, Nujūm, 7: 425-426, 511.

ai Ibid., 511, 763. See the discussion in Section 2.

aj Ibid., 647-648, 685 .

ak Ibid., 685-687, 733-734.

al Ibid., $733,814-815$.

am Ibid., 742-743, 821 .

an Ibid., 823,843 .

ao Ibid., 843,866 . 


\section{Bibliography}

\section{Primary Sources}

Al-'Aynī, 'Iqd al-Jumān fì Tārīkh Ahl al-Zamān: al-Hawādith wa-l-Tarājim min Sanat 815 h. ilā sanat 823 h., ed. A.Ṭ. al-Qarmūṭ (Cairo, 1985).

Al-Maqrīzī, Kitāb al-Sulūk li-Ma'rifat Duwal al-Mulūk, ed. S.A. 'Āshūr (Cairo, 1972-1973).

Al-Ṣayrafī, Nuzhat al-Nufūs wa-l-Abdān fì Tawārīkh al-Zamān, ed. Ḥ. Ḥabashī (Cairo, 1974).

Cicero, M. Tullius, The Orations of Marcus Tullius Cicero, literally translated by C.D. Yonge (London, 1856) (http://www.perseus.tufts.edu/hopper/, consulted June 30 2015).

Cicero, M. Tullius, M. Tulli Ciceronis Orationes. Tomus IV: Pro P. Quinctio. Pro Q. Roscio Comoedo. Pro A. Caecina. De lege agraria contra Rullum. Pro C. Rabirio perduellionis reo. Pro L. Flacco. In L. Pisonem. Pro C. Rabirio Postumo, ed. A.C. Clark [Scriptorum Classicorum Bibliotheca Oxoniensis] (Oxford, 1909) (http://www.perseus.tufts.edu/ hopper/, consulted June 2015).

Ibn Hajar al-'Asqalānī, Inbä'’ al-Ghumr bi-Abnä' al-'Umr (Beirut, 1986).

Ibn Iyās, Badā'i al-Zuhūr fì Waqā'i ${ }^{\prime}$ al-Duhūr, eds. M. Mustafa et al. (Cairo-Wiesbaden, 1960-1992).

Ibn Taghrībirdī, al-Nujūm al-Zāhira fì Mulūk Miṣr wa-l-Qāhira, ed. W. Popper [University of California Publications in Semitic Philology, vols. V-VII, XII, XIV, XVII-XIX, XXII] (Berkeley-Los Angeles, 1915-1960).

Ibn Taghrībirdī, Hawādith al-Duhūr fı̀ Madā al-Ayyām wa-l-Shuhūr, ed. W. Popper [University of California Publications in Semitic Philology, vol. viıI] (Berkeley-Los Angeles, 1930-1933).

Ibn Taghrībirdī, al-Manhal al-Ṣāfı́wa-l-Mustawfā ba'da l-Wāfì, ed. M.M. Amīn (Cairo, 1984-2009).

\section{Secondary Sources}

'Abd al-Jawād, Ismāc̄il Laylā, "Atābak al-'asākir fī l-Qāhira fī 'aṣr dawlat al-Mamālīk alBaḥriyya", al-Mu'arrikh al-Mișrī 10 (1993): 49-106.

Adriaenssens, Veerle \& Jo Van Steenbergen, "Mamluk authorities and Anatolian realities: Jānibak al-Ṣūfī, sultan al-Ashraf Barsbāy, and the story of a social network in the Mamluk/Anatolian frontier zone, $1435^{-1438}$, Journal of the Royal Asiatic Society 26/4 (2016): 591-630.

Algazi, Gadi, "Comparing Medieval Institutions. A Few Introductory Remarks", in J. Hudson and A. Rodríguez, eds., Diverging Paths? The Shapes of Power and Institutions in Medieval Christendom and Islam, eds. (The Medieval Mediterranean vol. 101) (Leiden-Boston, 2014), pp. 3-15. 
Algazi, Gadi, Valentin Groebner \& Bernhard Jussen, eds., Negotiating the Gift. PreModern Figurations of Exchange (Göttingen, 2003).

Ayalon, D., "Studies on the Structure of the Mamluk Army-III", Bulletin of the School of Oriental and African Studies 16/1 (1954): 57-90.

Ayalon, D., "Atābak al-'asākir", $E I^{2}$, I: $73^{2}$.

Beck, H., Karriere und Hierarchie. Die römische Aristokratie und die Anfänge des cursus honorum in der mittleren Republik (KLIO. Beiträge zur alten Geschichte) (Berlin, 2005).

Bodenhorn, Barbara \& Gabriele vom Bruck, "Entangled in Histories': An Introduction to the Anthropology of Names and Naming", in G. vom Bruck and B. Bodenhorn, eds., The Anthropology of Names and Naming (Cambridge, 2006), pp. 1-30.

Bourdieu, Pierre, "Rethinking the State: Genesis and Structure of the Bureaucratic Field", Sociological Theory 12/1 (1994):1-18.

Bourdieu, Pierre, "From the King's House to the Reason of State: A Model of the Genesis of the Bureaucratic Field", Constellations, 11/1 (2004): 16-36.

Brinner, William M., "The struggle for power in the Mamlûk state: Some reflections on the transition from Bahrî to Burjî rule", in Proceedings of the 26th International Congress of Orientalists, New Delhi, 4-1o January 1964 (New Delhi, 1970), pp. 231-234.

Cahen, Claude, “Atabak (atabeg)”, $E I^{2}$, I: 731-732.

Casey, Kimberley L., "Defining Political Capital: A Reconsideration of Bourdieu's Interconvertibility Theory", conference paper (2008).

Chamberlain, Michael, Knowledge and Social Practice in Medieval Damascus, 1190-1350 (Cambridge Studies in Islamic Civilization) (Cambridge, 1994).

Clifford, Winslow W., "Ubi Sumus? Mamluk History and Social Theory", Mamlūk Studies Review 1 (1997): 45-62.

D'hulster, Kristof, "Fixed Rules to a Changing Game? Sultan Mehmed II's Realignment of Ottoman-Mamluk Diplomatic Conventions with the International Power Constellation", in F. Bauden \& M. Dekkiche, eds., Mamluk Cairo. A Crossroad for Embassies. Proceedings of the Liège Conference, Sept. 6-8, 2012 (Leiden, 2019), pp. 484-508.

D'hulster, Kristof \& Jo Van Steenbergen, "Family Matters: The "Family-In-Law Impulse" in Mamluk Marriage Policy", Annales Islamologiques 47 (2013): 61-82.

Darling, Linda, "Political Change and Political Discourse in the Early Modern Mediterranean World", Journal of Interdisciplinary History 38/4 (2008): 505-531.

Eddé, Anne-Marie, "Quelques institutions militaires ayyoubides", in U. Vermeulen \& D. De Smet, eds., Egypt and Syria in the Fatimid, Ayyubid and Mamluk Eras (Orientalia Lovaniensia Analecta vol. 223) (Leuven, 1995), pp. 163-174.

Eychenne, Mathieu, "Le bayt à l'époque mamlouke. Une entité sociale à revisiter", $A n$ nales Islamologiques 42 (2008): 275-295. 
Finnegan, Ruth, Why Do We Quote? The Culture and History of Quotation (Cambridge, 2011).

Garcin, Jean-Claude, "The Regime of the Circassian Mamlūks", in Carl F. Petry, ed., The Cambridge History of Egypt, Volume I: Islamic Egypt, 640-1517 (Cambridge, 1998), pp. 290-317.

Hekster, Olivier, Emperors and Ancestors. Roman Rulers and the Constraints of Tradition (Oxford Studies in Ancient Culture \& Representation) (Oxford, 2015).

Hellegouarc'h, Joseph, Le vocabulaire latin des relations et des partis politiques sous la république (Paris, 1963).

Hirschler, Konrad, "He is a child and this land is a borderland of Islam': Under-age Rule and the Quest for Political Stability", al-Masāq 19/1 (2007): 29-46.

Holt, Peter M., "The position and power of the Mamlūk sultan", Bulletin of the School of Oriental and African Studies 38/2 (1975): 237-249.

Holt, Peter M., "The structure of government in the Mamluk Sultanate", in P.M. Holt, ed., The Eastern Mediterranean Lands in the Period of the Crusades (Warminster, 1977), pp. 44-61.

Hudson, John \& Ana Rodríguez, "Preface", in J. Hudson \& A. Rodríguez, Diverging Paths? The Shapes of Power and Institutions in Medieval Christendom and Islam (The Medieval Mediterranean vol. 101) (Leiden-Boston, 2014), pp. ix-xiii.

Humfress, Caroline, "Institutionalisation between Theory and Practice. Comparative Approaches to Medieval Islamic and Late Roman Law", in J. Hudson \& A. Rodríguez, Diverging Paths? The Shapes of Power and Institutions in Medieval Christendom and Islam (The Medieval Mediterranean vol. 101) (Leiden-Boston, 2014), pp. 16-29.

Irwin, Robert, The Middle East in the Middle Ages. The Early Mamluk Sultanate 1250-1382 (Carbondale-Edwardsville, 1986).

Kunkel, Wolfgang \& Roland Wittman, Staatsordnung und Staatspraxis der römischen Republik. Zweiter Abschnitt: Die Magistratur (Rechtsgeschichte der Altertums im Rahmen des Handbuchs der Altertumswissenschaft, III/2/2) (München, 1995).

Levanoni, Amalia, "The Mamluk conception of the sultanate", International Journal of Middle East Studies 26/3 (1994): 373-392.

Levanoni, Amalia, “Atābak (Atabeg)”, EI $I^{3}$, Brill Online (consulted June 2015).

Loiseau, Julien, "Lémir en sa maison. Parcours politique et patrimoine urbain au Caire, d'après les biographies du Manhal al-Ṣāfì", Annales Islamologiques 36 (2002): 117-137.

Mauss, Marcel, "Essai sur le don. Forme et raison de l'échange dans les sociétés archaïques", L’Année sociologique, Nouv. Série 1 (1923-1924): 30-186.

Meyer, Elizabeth A., "Explaining the Epigraphic Habit in the Roman Empire: The Evidence of Epitaphs", Journal of Roman Studies 80 (1990): 74-96.

MP 3 (Mamluk Political Prosopography Project, database partially available on www .mamluk.ugent.be/prosopography).

Nicols, John, Civic Patronage in the Roman Empire (Leiden, 2014). 
Petry, Carl F., Protectors or Praetorians? The Last Mamluk Sultans and Egypt's Waning as a Great Power (Albany, 1994).

Pierson, Paul, Politics in Time. History, Institutions, and Social Analysis (Princeton, 2004).

Popper, William, Egypt and Syria under the Circassian Sultans 1382-1468 A.D. Systematic Notes to Ibn Taghrî Birdîs Chronicles of Egypt (University of California Press Publications in Semitic Philology, vol. 15) (Berkeley-Los Angeles, 1955).

Rapoport, Yossef, "New Directions in the Social History of the Mamluk Era", in S. Conermann, ed., History and Society during the Mamluk Period (1250-1517) (Studies of the Annemarie Schimmel Research College, vol. 1) (Bonn: 2014), pp. 143-157.

Rustow, Marina, "Patronage in the Context of Solidarity and Reciprocity: Two Paradigms of Social Cohesion in the Premodern Mediterranean", in E. Alfonso \& J. Decter, eds., Patronage, Production, and Transmission of Texts in Medieval and Early Modern Jewish Cultures (Turnhout, 2014), pp. 13-44.

Schreyögg, Georg \& Jörg Sydow, "Understanding Institutional and Organizational Path Dependencies", in J. Sydow \& G. Schreyögg, eds., The Hidden Dynamics of Path Dependence. Institutions and Organizations (Basingstoke-New York, 2010), pp. $3^{-12 .}$

Şenturk, Recep, Narrative Social Structure. Anatomy of the Hadith Transmission Network 610-1505 (Stanford, CA, 2005).

Sewell Jr., William H., Logics of History. Social Theory and Social Transformation (Chicago \& London: Chicago University Press, 2005).

Sievert, Henning, "Der Kampf um die Macht im Mamlukenreich des 15. Jahrhunderts", in A. Pistor-Hatam \& St. Conermann, eds., Die Mamluken. Studien zu ihrer Geschichte und Kultur. Zum Gedenken an Ulrich Haarmann (1942-1999) (Hamburg, 2003), pp. $335-366$.

Sievert, Henning, Der Herrscherswechsel im Mamlukensultanat. Historische und historiographische Untersuchungen zu Abū Hāmid al-Qudsī und Ibn Taġrībirdī (Islamkundliche Untersuchungen, vol. 254) (Berlin, 2003).

Sievert, Henning, "Family, friend or foe? Factions, households and interpersonal relations in Mamluk Egypt and Syria", in S. Conermann, ed., Everything is on the Move. The Mamluk Empire as a Node in (Trans-)Regional Networks (Bonn, 2014), pp. 83-126.

Stewart, Angus D., "Between Baybars and Qalāwūn: Under-age Rulers and Succession in the Early Mamlūk Sultanate", al-Masāq 19/1 (2007): 27-54.

Tilly, Charles, Big Structures, Large Processes, Huge Comparisons (New York: Russell Sage Foundation, 1984).

Van Steenbergen, Jo, Order Out of Chaos. Patronage, Conflict and Mamluk Socio-Political Culture, 1341-1382 (Leiden-Boston, 2006).

Van Steenbergen, Jo, “Is anyone my guardian...?' Mamlūk Under-age Rule and the Later Qalāwūnids", al-Masaq 19/1 (2007): 55-65. 
Van Steenbergen, Jo, "The Mamluk Sultanate as a Military Patronage State: Household Politics and the Case of the Qalāwūnid Bayt (1279-1382)", JESHO, 56/2 (2013): 189-2017.

Van Steenbergen, Jo, “Mamlukisation' between social theory and social practice: An essay on reflexivity, state formation, and the late medieval sultanate of Cairo [ASK Working Paper XXII]" (Bonn, 2015).

Van Steenbergen, Jo, Patrick Wing \& Kristof D'hulster, “The Mamlukisation of the Mamluk Sultanate? State Formation and the History of Fifteenth Century Egypt and Syria: Part II-Comparative Solutions and a New Research Agenda", History Compass 14/11 (2016): 560-569.

Van Steenbergen, Jo, Patrick Wing \& Kristof D'hulster, “The Mamlukisation of the Mamluk Sultanate? State Formation and the History of Fifteenth Century Egypt and Syria: Part I-Old Problems and New Trends", History Compass, 14/11 (2016): 549-559.

Wacquant, Loïc J.D., “On the Tracks of Symbolic Power: Prefatory Notes to Bourdieu's 'State Nobility", Theory, Culture \& Society, 10/1 (1993): 1-17.

Wang, Yingyao \& Simone Polillo, "Power in Organizational Society: Macro, Meso and Micro", in S. Abrutyn, ed., Handbook of Contemporary Sociological Theory (Springer, 2016) pp. 43-62.

Wex, C., "On the Leges Annales of the Romans", The Classical Museum. A Journal of Philology, and of Ancient History and Literature, 3 (1846): 405-416.

White, Harrison, Chains of Opportunity. System Models of Mobility in Organizations (Cambridge, Mass., 1970).

Yalçın, M. Fatih, "A path to throne among the Mamluks in early period: Na'ib al-Saltana (Regent of reign) [sic]", Tarih Okulu Dergisi/Journal of History School 20 (2014): $81-96$. 